\title{
LA IGLESIA CATÓLICA EN IBEROAMÉRICA: \\ LAS INSTITUCIONES \\ LOCALES EN UNA ÉPOCA DE CAMBIOS (SIGLO XVIII)
}

Contacto

Díaz Colodrero 3338 - depto. 4 1431 - Ciudad Autónoma de Buenos Aires - Argentina E-mail: mebarral@yahoo.com

\section{María Elena Barral*}

Universidad Nacional de Luján

\section{Resumen}

El presente artículo considera de modo general el conjunto de las reconfiguraciones en el ámbito religioso que tuvieron lugar en Iberoamérica durante el siglo XVIII. De modo específico busca mostrar a partir de la bibliografía disponible un orden de procesos no demasiado visible en torno al papel de algunas instituciones eclesiásticas y religiosas - como las parroquias y las cofradías - en los procesos de estructuración social y política, así como las consecuencias de un tipo de intervención política como el que se verifica durante las reformas borbónicas y pombalinas.

\section{Palabras clave}

Regalismo - parroquias - cofradías.

* Professora adjunta do Departamento de História da Universidade Nacional de Luján, pesquisadora do Consejo Nacional de Investigaciones Científicas y Técnicas - Conicet, doutora em História pela Universidade Pablo de Olavide. 


\title{
THE CATHOLIC
}

CHURCH IN IBERO-

AMERICA:

LOCAL INSTITUTIONS

IN A CHANGING ERA

(EIGHTEENTH CENTURY)

Contact

Díaz Colodrero 3338 - depto. 4

1431 - Ciudad Autónoma de Buenos Aires - Argentina

E-mail: mebarral@yahoo.com

María Elena Barral

Universidad Nacional de Luján

\begin{abstract}
In a general view, this article considers the total of changing configurations of the religious sphere in Ibero-America during the eighteenth century. Specifically, this article intends to show how a not so visible order of processes around ecclesiastical and religious institutions such as parishes and confraternities impacted on the social and political structure. In addition, this article delves into the consequences of the Bourbon and Pombaline reforms in these events.
\end{abstract}

\section{Keywords}

Royal policies - parishes - confraternity. 
REVISTA DE HISTÓRIA

SÃO PAULO, N ${ }^{\circ} 169$, p. 145-180,

JULHO / DEZEMBRO 2013
María Elena Barral

La Iglesia católica en Iberoamérica: las instituciones locales en una época de cambios (siglo XVIII)

\section{Introducción}

El siglo XVIII fue una época de cambios para las instituciones y agentes eclesiásticos en Iberoamérica. La búsqueda de la homogeneidad y de la modernización - un imperativo de los monarcas ibéricos en su configuración "déspotas ilustrados" - convertía a la Iglesia en un obstáculo. O al menos la Iglesia que había desplegado su acción en América hasta el momento, es decir: con amplias prerrogativas y privilegios. El conjunto de medidas de corte regalista que se pusieron en práctica desde comienzos del siglo XVIII, y más decididamente en su segunda mitad, buscaban intervenir y modificar como se haría en otros ámbitos de la vida política - la sólida trama de intereses y acuerdos locales que las distintas órdenes religiosas y otras instituciones eclesiásticas habían construido desde sus específicos ámbitos de poder.

Los estudios sobre este proceso han mirado de modo especial los trazos generales del proyecto regalista y la reconfiguración que impulsaba al interior de la Iglesia y de la monarquía católica. En otras palabras: se ha analizado la profusa normativa que buscaba situar en un nuevo lugar a las instituciones y agentes eclesiásticos y, para los casos de mayor impacto como la expulsión de los jesuitas o la consolidación de vales reales -, se han examinado algunos aspectos de su aplicación y de sus consecuencias.

Sin embargo, otros estudios centrados en las instituciones eclesiásticas y religiosas locales han descubierto en este proceso una alteración más profunda y de consecuencias políticas más amplias tanto porque afectaron no solamente a miembros del clero como por su impacto en los lazos de obediencia que habían asegurado el dominio colonial a lo largo de más de dos siglos. Así, pese a que el fervor religioso no parece haber disminuido lo que estas reformas provocaron fue una lenta erosión de las lealtades y legitimidades.

Algunas disposiciones, en el caso específico del programa reformista borbónico, tuvieron como destinatarios privilegiados a los eclesiásticos, como la reforma del clero regular, la expulsión de los jesuitas, la secularización de las parroquias de indios o doctrinas o la notable reducción de las competencias judiciales del clero secular. Uno de los resultados más obvios de esta batería de medidas fue la deserción de los curas en tanto defensores incondicionales del régimen colonial. Pese a que la experiencia del reformismo borbónico no los convirtió en rebeldes - y muchos de ellos, por otra parte, habían propiciado los cambios - un sector del clero tomó distancia del rol político que se les había asignado desde los primeros tiempos coloniales: es decir como guardianes del orden y la moral públicos a nivel de las localidades. De este modo, monarquía perdía a una parte de los curas como 
REVISTA DE HISTÓRIA

SÃO PAULO, N ${ }^{\circ} 169$, p. 145-180,

JULHO / DEZEMBRO 2013
María Elena Barral

La Iglesia católica en Iberoamérica: las instituciones locales en una época de cambios (siglo XVIII)

- indispensables -informantes e incluso como sus representantes, lesionando así a una de las piezas clave de su control social y de su sostén ideológico. ${ }^{1}$

Otras medidas sumaron nuevos afectados, como la consolidación de vales reales, la fiscalización de las cofradías y la prédica ilustrada que condenaba las prácticas religiosas "barrocas". Muchas de estas innovaciones provocaron desequilibrios en las comunidades locales en la medida que alteraron un tipo de acuerdo construido en la relación con las instituciones religiosas. Un difícil equilibrio negociado entre obligaciones y expectativas en el ámbito de las instituciones -parroquias y cofradías - y de las prácticas religiosas locales se veía amenazado.

El presente artículo busca considerar en general el conjunto de las reconfiguraciones que tuvieron lugar en estos años y analizar, de modo específico, algunas de sus consecuencias a nivel de las comunidades locales. Se trata de mostrar a partir de una parte de la bibliografía disponible un orden de procesos no demasiado visible en torno al papel de algunas instituciones eclesiásticas y religiosas - como las parroquias y las cofradías - en los procesos de estructuración social y política, así como las consecuencias de un tipo de intervención política como el que se verifica durante las reformas borbónicas y pombalinas. ${ }^{2}$

El artículo presenta en primer lugar el contexto general del siglo XVIII y las principales líneas de transformación sostenidas por las monarquías ibéricas en el ámbito religioso. Luego analiza la parroquia en algunas de las modalidades que asumió en los territorios americanos y su papel en distintos contextos regionales y culturales. Por último considera las cofradías y algunas de las respuestas que desde ellas formularon algunas comunidades indígenas y africanas/afrodescendientes.

\footnotetext{
TAYLOR, William, El camino de los curas y de los Borbones hacia la modernidad. In: MATUTE, Á., TREJO, E. y CONNAUGHTON, B. (coords.). Estado, Iglesia y sociedad en México, siglo XIX. México: Unam-Miguel Ángel Porrúa ed., 1995, p. 81-113.

2 Se trata de una aproximación que no pretende ser exhaustiva en el sentido de dar cuenta de la totalidad de la producción historiográfica sobre estos temas. De este modo sólo se consideran algunas de las contribuciones que en función del contenido y tratamiento de los temas permiten desarrollar mejor los ejes de análisis propuestos. Algunos temas de gran relevancia que podrían formar parte de este análisis no están presentes aquí por una cuestión de espacio: como la expulsión de los jesuitas, el tipo de reacciones que se verifican en distintos contextos regionales y la reestructuración de un tipo de experiencia particular como lo fueron las reducciones del Paraguay.
} 


\section{Las grandes líneas de acción de las coronas ibéricas en el dominio eclesiástico}

Desde mediados del siglo XVIII las monarquías ibéricas buscaron resituar a las instituciones eclesiásticas en el nuevo diseño político. En el caso de la corona española, durante las primeras décadas del siglo XVIII, intentó ajustar sus relaciones con la Santa Sede que se habían visto tensionadas durante la guerra de secesión y, en este contexto, Felipe V reclamó los derechos de patronato para el conjunto de sus dominios. ${ }^{3}$ Esta pretensión profundizó la crisis y condujo a la ruptura de relaciones con el papado que sólo pudo resolverse hacia 1753 con la firma de un Concordato que consagraba algunas de las pretensiones reales. En el caso de Portugal la ruptura de relaciones con el papado se produjo a partir de la expulsión del nuncio apostólico de Lisboa en 1760 y duró una década. De un modo paulatino se operaba una cierta secularización de la relación política que buscaba desplazar la idea de misión providencial de las coronas ibéricas, hasta el momento en el centro de la cultura post-tridentina.

La idea rectora se dirigía a eliminar los diversos polos de poder entre el clero y la Corona y constituía una parte de los esfuerzos por transformar la monarquía compuesta y horizontal, en una monarquía vertical. ${ }^{4}$ Por eso se reforzó el uso del pase regio o exequátur. ${ }^{5} \mathrm{Al}$ mismo tiempo se pretendía modelar una Iglesia dócil que se ajustara - y limitara - a las cuestiones espirituales del dogma, la liturgia y los sacramentos. Distintas reales cédulas buscaron asegurar al monarca español el control directo del clero y se celebraron Concilios a partir de 1771 en México y Lima para concretar algunas de estas líneas generales en acción y con el fin de organizar la disciplina

\footnotetext{
Sólo gozaban de patronato universal Granada Filipina e Indias, por derecho de conquista.

${ }^{4}$ ELLIOT, John. Rey y patria en el mundo hispánico. In: MÍNGUEZ, V. y CHUST, M. El imperio sublevado. Monarquía y naciones en España e Hispanoamérica. Madrid: CSIC, 2004, p. 17-36.

5 A través del pase regio o exequatur los monarcas aprobaban las disposiciones pontificias para que fueran observadas dentro de sus dominios.
} 
REVISTA DE HISTÓRIA

SÃO PAULO, N ${ }^{\circ} 169$, p. 145-180,

JULHO / DEZEMBRO 2013
María Elena Barral

La Iglesia católica en Iberoamérica: las instituciones locales en una época de cambios (siglo XVIII)

clerical. $^{6}$ El perfil del clero de los borbones era el de un buen pastor: un maestro respetuoso.?

Y precisamente los jesuitas no eran vistos de ese modo por los reformistas borbónicos y pombalinos. Hasta entonces, la Compañía de Jesús había sido una firme aliada de las monarquías ibéricas y había tenido notable influencia en dotarla de una acendrada mentalidad contrarreformista. Las prédicas jesuitas sirvieron para construir el edificio ideológico y simbólico de monarquías que se veían a sí mismas como católicas. Sin embargo, el tradicionalismo jesuita entraba a mediados del siglo XVIII en abierta contradicción con las pretensiones regalistas de las coronas al tiempo que este regalismo exigía una reformulación de los fundamentos de legitimación de las propias monarquías. ${ }^{8}$ Sin duda, el momento culminante y más dramático de esta confrontación fue la expulsión de la Compañía de Jesús de todos los territorios imperiales de Portugal en 1759 y de España en 1767. Así, las expulsiones barrían con el mayor grupo de oposición a la política regalista.?

El nuevo imaginario político que estaba formulando la monarquía no buscaba su legitimación tanto en su misión trascendente sino que ahora encontraba argumentos en fines más terrenales, pragmáticos y utilitarios. La "prosperidad" del reino acompañaba la meta del "bien común" y de la "utilidad" de sus habitantes y era postulada como un valor tan importante como su religiosidad. Para realizar esta vasta empresa la Corona tuvo el apoyo y la colaboración, tanto del clero ilustrado como de integrantes de otras órdenes que, aunque no fueran entusiastas partícipes de la nueva sensibilidad, veían en la expulsión una ocasión inmejorable para acrecentar su influencia.

\footnotetext{
${ }^{6}$ De esta manera se buscaba concretar la idea de Carlos III de confiar a los propios Concilios americanos - y a sus prelados - la reforma de la administración de la Iglesia. DE LA HERA, Alberto. El regalismo indiano. Ius Canonicum, n 64 . Pamplona: EUNSA, 1992, p. 411-437. En el caso de Portugal durante la mayor parte del siglo XVIII estuvieron vigentes Constituições Primeiras do Arcebispado da Bahia. FEITLER, Bruno y SALES SOUZA, Evergton (orgs.). A Igreja no Brasil: Normas e práticas durante a vigência das Constituições Primeiras do Arcebispado da Bahia. São Paulo: Editora Unifesp, 2011. RODRÍGUEZ, Antonio Acosta. La reforma eclesiástica y misional (siglo XVIII). In: TANDETER, E. e LEHUEDÉ, J. Hidalgo (dirs.). Historia general de América Latina, v. IV. París-Madrid: Unesco/ Editorial Trotta, 2000, p. 349-374.

${ }^{8}$ FRADKIN, Raúl y GARAVAGLIA, Juan Carlos. La Argentina colonial. El Río de la Plata entre los siglos XIV $y$ XIX. Buenos Aires: Siglo XXI, 2009.

9 En Hispanoamérica se registran reacciones frente a la expulsión que por cuestiones de espacio no desarrollamos en este artículo. Puede verse el excelente análisis de MEDRANO, Carlos Rubén Ruiz. El tumulto de 1767 en Guanajuato. Estudios de Historia Novohispana, v. 19. México: Unam, 1999, p. 13-46.
} 
REVISTA DE HISTÓRIA

SÃO PAULO, N 169 , p. 145-180,

JULHO / DEZEMBRO 2013
María Elena Barral

La Iglesia católica en Iberoamérica: las instituciones locales en una época de cambios (siglo XVIII)

Por su parte, las propiedades eclesiásticas de "manos muertas" y exentas de tributación eran imposibles de admitir en el proyecto borbónico. El argumento principal para echar mano de ellas a través de diferentes mecanismos se dirigía a señalarlas como una de las causas del atraso económico y de las menguadas rentas reales. La consolidación de vales reales (un sistema peculiar de bonos de la deuda estatal) fue anunciada por la Corona en 1804 para confiscar el capital de las reservas corporativas de la Iglesia a cambio de un interés anual. El sistema había sido aplicado en España y en 1804 se extendía a América. Al mismo tiempo, esta medida debe evaluarse en el marco de las tendencias desamortizadoras imperantes en Europa desde principios del siglo XVIII, que consistían en la expedición y aplicación, por parte de las autoridades civiles, de una serie de leyes mediante las cuales se liberaban los bienes amortizados. ${ }^{10}$

En efecto, se trataba de capitales - en especial de capellanías y obras pías - sometidos a consolidación. Una parte muy importante de las unidades productivas se encontraba endeudada con diversas instituciones eclesiásticas por operaciones de crédito y muchos hacendados, pero también comerciantes, intervenían regularmente en este tipo de operaciones. La enajenación se concibió como un préstamo. Los dueños de los capitales recibían escrituras por los montos de las cantidades entregadas y la Corona se comprometía a pagar intereses de un 5\% anual sobre dichos capitales. El préstamo se garantizaba mediante diferentes ramos de las rentas reales y, como la puesta en práctica de la disposición implicó la obligación de pagar considerables cantidades de dinero por parte de los afectados que con frecuencia no poseían por falta de circulante, se otorgó crédito a través de un mecanismo llamado composición.

Esta medida, sin embargo, formaba parte de los esfuerzos de la Corona por extraer recursos de América junto a la vía fiscal y a las demandas de crecientes donativos y - aunque no llegó a concretarse ni en su totalidad ni en los montos previstos - fue muy impopular en varios sentidos: por un lado podía enajenar la lealtad de muchos eclesiásticos - que como magistrados reales habían sostenido durante siglos la legitimidad política de la Corona - y, por el otro, las elites podían verse defraudadas en sus vínculos con la monarquía. ${ }^{11}$

\footnotetext{
${ }^{10}$ Es decir los bienes que por distintos mecanismos se habían sustraído a la circulación - o de "manos muertas", como se aludía a ellos frecuentemente - y podían pertenecer no sólo a las instituciones eclesiásticas sino también a los municipios y mayorazgos.

${ }^{11}$ GARAVAGLIA, Juan Carlos y MARCHENA, Juan. América Latina. De los orígenes a la Independencia, v. 2. Barcelona: Crítica, 2005.
} 
REVISTA DE HISTÓRIA

SÃO PAULO, N ${ }^{\circ} 169$, p. 145-180,

JULHO / DEZEMBRO 2013
María Elena Barral

La Iglesia católica en Iberoamérica: las instituciones locales en una época de cambios (siglo XVIII)

En el caso particular - y central - de Nueva España el real decreto de consolidación se aplicó de manera muy estricta. Como lo plantea Gisela von Wobeser la medida afectó a distintos grupos o instituciones de diferente manera. ${ }^{12}$ Las instituciones religiosas del clero secular y del regular, las educativas, de salud y de beneficencia se vieron descapitalizadas. ${ }^{13}$ Los titulares de las fundaciones pías se vieron perjudicados en tanto se les privó de las rentas, del mismo modo que sus beneficiarios - que en la mayor parte de los casos eran legos - que perdían fuentes de financiamiento para ordenarse como sacerdote o para entrar al convento. Por último, los deudores de capitales pertenecientes a instituciones eclesiásticas o a fundaciones piadosas debían redimir los principales de las cantidades adeudadas y la redención forzosa de los capitales adeudados significó la quiebra de muchas unidades productivas. ${ }^{14}$

En el caso de Portugal, cuando el príncipe don Juan asumió en carácter provisorio los asuntos del estado entre 1792 y 1799 - y sobre todo hasta 1801 cuando fue declarado oficialmente regente - los empréstitos forzosos para hacer frente a los crecientes gastos militares constituyeron un foco de tensión entre las distintas corporaciones eclesiásticas y la Corona. Distintas medidas se dirigían a las corporaciones de manos muertas - órdenes religiosas, hermandades, colegios, hospitales - a quienes se las intimaba a liquidar su rico patrimonio inmobiliario. Se trataba de un empréstito forzoso, que ya contaba con antecedentes en algunas medidas de la etapa pombalina como la legislación relativa a los testamentos que prohibía a las órdenes religiosas, ordenes terceras o a otras corporaciones su ejecución o la limitación del valor de los legados que podían ser dejados en beneficio de las almas. Dentro del programa reformista de Rodrigo Souza Coutinho, secretario de Marina y Ultramar desde 1796 se continuaron y profundizaron muchas de las líneas políticas de Sebastião José de Carvalho e Melo, marqués de Pombal, como la racionalización de las finanzas públicas que también afectaba a las instituciones ecle-

\footnotetext{
$\overline{12}$ WOBESER, Gisela von. El crédito eclesiástico en la Nueva España, siglo XVIII. México: Unam, 1994.

${ }^{13}$ En un primer momento, las Cajas de Consolidación pagaron los réditos de las cantidades enajenadas, pero a partir de 1807 los pagos empezaron a retrasarse y desde 1810 directamente se suspendieron.

${ }^{14}$ Era evidente que estos deudores - hacendados, comerciantes, mineros - poseían bienes hipotecados como consecuencia del tipo de actividad crediticia propia de una economía caracterizada por la escasez de circulante, que las deudas solían mantenerse por periodos muy largos y que los prestatarios pagaban los réditos correspondientes a los principales sin redimir los capitales.
} 
REVISTA DE HISTÓRIA

SÃO PAULO, N 169 , p. 145-180,

JULHO / DEZEMBRO 2013
María Elena Barral

La Iglesia católica en Iberoamérica: las instituciones locales en una época de cambios (siglo XVIII)

siásticas. Sin embargo su impacto fue variable y en el caso de Río de Janeiro los resultados "tímidos" con relación a las necesidades del erario regio. ${ }^{15}$

Algunas interpretaciones disponibles sobre estas reformas han planteado en general la idea de "una Iglesia asediada" en el marco de esta nueva política imperial. David Brading ha resumido esta interpretación con gran claridad: "la Iglesia mexicana sufrió un asalto sin precedentes, iniciado por ministros y funcionarios que se jactaban de sus ideas ilustradas, mostraban una creciente envidia a la riqueza del clero y temían su influencia sobre los fieles". ${ }^{16}$ En la misma dirección hemos visto las consecuencias políticas que se le atribuyen a la aplicación del decreto de consolidación de vales reales. Sin embargo esta no es la única interpretación disponible acerca de las relaciones entre Estado e Iglesia y otros autores han enfatizado la presencia de un clero ilustrado adicto a las reformas e incluso militando activamente en las filas de los reformadores. En Brasil, la política eclesiástica contó con un firme apoyo de los obispos quienes sostuvieron el proyecto pombalino y buscaron difundir los principios eclesiológicos regalistas-galicanos. ${ }^{17}$

Por último el conjunto de reformas que afectaron al clero parroquial - y a sus feligresías - de manera directa como la secularización de las parroquias o la uniformización de los aranceles eclesiásticos ${ }^{18}$ tenían un objetivo preciso: modelar un nuevo lugar para los curas. Este nuevo sitio implicaba una mudanza: debían dejar de ser magistrados para convertirse en administradores u "hombres de regla fija". Esta alteración implicaba una sensible pérdida de autonomía y modificaba un tipo de posición construida - y sobre todo negociada - entre párrocos y feligreses. La decisión de modificar esos vínculos suponía riesgos. Este artículo analiza algunas de las consecuencias de estas delicadas intervenciones.

\footnotetext{
${ }^{15}$ MARTINS, William de Souza. Membros do corpo místico. Ordens terceiras no Rio de Janeiro (c. 1700-1822). São Paulo: Edusp, 2009. Hacia 1800 sólo cuatro corporaciones se encontraban ejecutando las medidas y muchas de las que no lo hacían se excusaban argumentando la insignificancia de su patrimonio inmobiliario.

${ }^{16}$ BRADING, David. Una Iglesia asediada: el obispado de Michoacán, 1749-1810. México: FCE, 1994, p. 21.

${ }_{17}$ SOUZA, Evergton Sales. Igreja e Estado no período pombalino. Lusitania Sacra, nº 23, 2011, p. 207-230.

${ }^{18}$ Los derechos percibidos en concepto de misas, bautismos, matrimonios, entierros u otros servicios religiosos se encontraban estipulados por tarifas arancelarias diocesanas.
} 


\section{Las parroquias: encuadramiento social e institucionalización}

El papel de las parroquias como lugares de institución o estructuras de encuadramiento religioso y social ha sido señalado en los estudios sobre sus orígenes en la época medieval. ${ }^{19}$ Estos trabajos han puesto en evidencia la articulación entre las estructuras de encuadramiento religioso y el territorio y han descripto el largo proceso a través del cual la parroquia comenzó a definirse en términos de territorio entre el siglo IX y mediados del siglo XIII. La importancia decisiva de las parroquias en los procesos de institucionalización y territorialización en este contexto reside en haber constituido la primera red administrativa a escala de la localidad.

Al mismo tiempo se ha señalado el papel de las prácticas sociales y culturales - y religiosas como la obligación de bautizar a los recién nacidos y de inhumar a los difuntos - en su delimitación. ${ }^{20}$ De este modo las parroquias pueden ser pensadas, además de como unidades de la fiscalidad laica y/o eclesiástica, como espacios de negociación constantemente redefinidos por los usos y como espacios de reivindicación de pertenencias por parte de las poblaciones locales. En este sentido la parroquia continuaba siendo una comunidad de fieles luego de verificarse su territorialización.

El término parroquia designaba además una relación de poder. Evocaba el vínculo que debía ligar al grupo de fieles con la autoridad eclesiástica, el obispo, así como el desplazamiento de éste último y el circuito que representaba la visita episcopal. Al mismo tiempo podía remitir a la idea de circulación de los fieles hacia el lugar de culto con el fin de recibir los sacramentos o pagar el diezmo. La polisemia del término nos devuelve los múltiples sentidos y funcionalidades de la institución.

El análisis de la institución en su versión iberoamericana de la época colonial requiere agregar nuevos sentidos otorgados por la intervención de distintos agentes y el desarrollo de diferentes experiencias históricas. En este sentido William Taylor muestra cómo en los pueblos de indios de México

\footnotetext{
${ }^{19}$ IOGNA-PRATT, Dominique y ZADORA-RIO, Élisabeth. Formation et transformations des territoires paroissiaux. Médiévales, $\mathrm{n}^{\circ} 49$, 2005, p. 5-10; ZADORA-RIO, Élisabeth. Territoires paroissiaux et construction de l'espace vernaculaire. Médiévales, nº 49, 2005, p. 105-120; LAUWERS, Michel. Paroisse, paroissiens et territoire. Remarques sur parochia dans les textes latins du Moyen Âge. Médiévales, n 49, 2005, p. 11-32.

${ }^{20}$ LAUWERS, Michel, Paroisse, op. cit., 2005, p. 6: El arzobispo de Lyon en 853 definía la parroquia como "el lugar dónde los fieles comulgan, se confiesan, pagan el diezmo y son sepultados".
} 
REVISTA DE HISTÓRIA

SÃO PAULO, N 169 , p. 145-180,

JULHO / DEZEMBRO 2013
María Elena Barral

La Iglesia católica en Iberoamérica: las instituciones locales en una época de cambios (siglo XVIII)

central y Oaxaca, el templo y sus terrenos eran considerados lugares sagrados que conectaban el pasado, el presente y el futuro de estas comunidades sometidas en el contexto de la conquista europea. Muchas de estas capillas y parroquias fueron construidas en los mismos lugares sagrados que ocupaban los dioses prehispánicos - y a veces hasta con las mismas piedras - y dentro de sus terrenos se encontraba el cementerio, lo cual ligaba aún más a la comunidad con su pasado. La Iglesia, su atrio y su cementerio, podían servir entonces como lugares simbólicos de habitación y como espacios de fuerte cohesión comunitaria, en particular, en contextos de protestas colectivas.

En los motines de pueblo que se registran en estas mismas zonas y para cuya caracterización global Taylor propone la noción de "campanilismo", ${ }^{21}$ la iglesia parroquial era el lugar donde se centralizaba la acción comunitaria. Según su reconstrucción la gente del pueblo con frecuencia se reunía en el atrio para tener alguna noticia antes de lanzarse sobre el enemigo. Y la elección de este lugar no era azarosa: el atrio era un espacio de congregación comunal donde tenían lugar las explicaciones de doctrina cristiana que eran de asistencia obligatoria. Pero también era el lugar de reunión de la comunidad más allá de las obligaciones como feligreses. Era un lugar para hacer negocios o para intercambiar información: "una arena viviente donde se tomaban las decisiones de la comunidad y se realizaba la actividad colectiva".22 Así la Iglesia, al tiempo que perseguía sus propios objetivos a través de algunas instituciones locales como las parroquias o las cofradías, alimentaba las responsabilidades comunales reforzando este rasgo comunitario dentro del mundo indígena.

Entre algunas de las decisiones borbónicas que me interesa analizar y, sobre todo, considerar las transformaciones que acarreó en el plano local - se encuentra la secularización de las parroquias de indios o doctrinas, es decir el cambio de titularidad de estas parroquias y su asignación al clero secular. ${ }^{23}$ Se trataba de una medida que, aunque no era nueva, se generalizó y reforzó

\footnotetext{
${ }^{21}$ Se refiere a una visión del mundo "localocéntrica" que tendía a pensar que el mundo terminaba, metafóricamente, en el horizonte visto desde el campanario del pueblo.

${ }^{22}$ TAYLOR, William. Embriaguez, homicidio y rebelión en las poblaciones coloniales mexicanas. México: FCE, 1987, p. 179.

${ }^{23}$ Un estudio del proceso en la provincia franciscana de Jalisco: CURIEL, José Refugio de las Torres. Vicarios en entredicho. Zamora/Guadalajara: El Colegio de Michoacán, Universidad de Guadalajara, 2001.
} 
REVISTA DE HISTÓRIA

SÃO PAULO, N ${ }^{\circ} 169$, p. 145-180,

JULHO / DEZEMBRO 2013
María Elena Barral

La Iglesia católica en Iberoamérica: las instituciones locales en una época de cambios (siglo XVIII)

a partir de 1749 (y sobre todo en la década de 1760 cuando comenzaron a concretarse las secularizaciones de esta etapa). ${ }^{24}$

En línea con los principales ejes del pensamiento regalista, la medida era parte de un conjunto de reformas que buscaban fortalecer al clero secular y sus instituciones así como la autoridad y control de los obispos sobre el clero y sobre las feligresías. Entre las medidas complementarias se encuentran la instalación de seminarios para la formación del clero en algunas diócesis, la división de curatos y el aumento del número de eclesiásticos auxiliares. En México por ejemplo la necesidad de cubrir las parroquias de indios secularizadas aumentó la demanda de "clérigos lenguas", es decir aquellos sacerdotes que habían sido ordenados por su conocimiento de las lenguas indígenas y, a su vez, significó la apertura de una vía de acceso cada vez más amplia de sectores indígenas al sacerdocio. ${ }^{25}$ En contraste la reforma de las órdenes regulares buscaba fiscalizar el funcionamiento de los conventos a través de la designación de visitadores, establecer un número mínimo de frailes en las distintas residencias, la restauración de la vida en común y la vida claustral, la fiscalización y organización de las rentas (que caracterizaban como arbitrarias y desordenadas) y "reformar la relajación de costumbres". El ideal de centralización y uniformidad se traducía en algunas consignas básicas, entre ellas resalta una: "reglas fijas y obediencia a la ley sin interpretación".26

El impacto causado por la secularización de las parroquias en algunas zonas, como Jalisco en México, fue bastante más importante e imprevisible para los reformistas borbónicos que lo que pudieron haber imaginado antes de su aplicación. Estas parroquias habían sido administradas por los franciscanos desde los primeros tiempos de la colonia quienes impulsaron la creación de instituciones comunales como los hospitales de indios y tam-

\footnotetext{
${ }^{24}$ SALVADOR, Rodolfo Aguirre. La secularización de doctrinas en el arzobispado de México: realidades indianas y razones políticas, 1700-1749. Hispania Sacra, v. 60, $\mathrm{n}^{\circ} 122$, julio-diciembre 2008, p. 487-505 y SALVADOR, Rodolfo Aguirre. José Lanciego, arzobispo de México, y el clero regular durante la transición eclesiástica del reinado de Felipe V, 1712-1728. Fronteras de la Historia, v. 17-2/2012, p. 75-101; MAZIN, Oscar; MENEGUS, Margarita y MORALES, Francisco. La secularización de las doctrinas de indios en la Nueva España. La pugna entre las dos iglesias. México: Bonilla Artiaga Editores/Unam, 2010; PUENTE, Leticia Pérez. Dos proyectos postergados. El tercer Concilio Provincial mexicano y la secularización parroquial. Estudios de Historia Novohispana, $\mathrm{n}^{\circ}$ 35, julio-diciembre 2006, p. 17-45; SALAS, Adriana Rocher. Frailes y clérigos en Yucatán, siglo XVII. Hispania Sacra, v. 55, nº 112. Madrid: CSIC, 2003, p. 600-625.

${ }^{25}$ SALVADOR, Rodolfo Aguirre. La demanda de clérigos "lenguas" del arzobispado de México, 1700-1749. Estudios de Historia Novohispana, n 35, 2006, p. 47-70.

${ }^{26}$ TAYLOR, William. El camino de los curas, op. cit., 1995, p. 90.
} 
REVISTA DE HISTÓRIA

SÃO PAULO, N 169 , p. 145-180,

JULHO / DEZEMBRO 2013
María Elena Barral

La Iglesia católica en Iberoamérica: las instituciones locales en una época de cambios (siglo XVIII)

bién organizaron cofradías dedicadas a la Inmaculada Concepción. ${ }^{27}$ Como veremos más adelante, las cofradías habían adquirido una importancia decisiva en la organización de la vida comunitaria en distintas zonas de Iberoamérica y se habían convertido en instituciones activas desde el punto de vista de su intervención en la economía local. Tanto las cofradías como los hospitales - y sus capillas - cobraron una creciente importancia económica a medida que declinaban otras instituciones comunitarias como las tierras comunales o las cajas de comunidad. Progresivamente estas instituciones se convirtieron en centros de las actividades y sentimientos comunitarios, desplazando, inclusive, a las parroquias. El traspaso de las parroquias al clero secular supuso un debilitamiento de la atención espiritual, mientras que otras medidas complementarias alteraron estas adaptaciones creativas que las comunidades habían construido en torno a las instituciones eclesiásticas.

Es el caso de las medidas que echaron mano de los recursos de las cofradías que - como se analiza más adelante -, en el contexto de escasez de tierras, aumento de población, sequías y hambrunas, habían funcionado como bienes de la comunidad y colaboraban en el pago del tributo o de los litigios por tierras. Los nuevos párrocos cuestionaban este uso, tolerado y promovido por los religiosos franciscanos, y señalaban que estos bienes debían utilizarse sólo con fines religiosos.

Según Taylor estas medidas debilitaron la lealtad a la Corona y perturbaron los vínculos de obediencia frente a las autoridades en la medida en que se profundizaba el enfrentamiento entre los pueblos y los párrocos. El cuestionamiento del párroco - un mediador entre los súbditos y la Corona y, al mismo tiempo, un magistrado/administrador real - abría el camino hacia la ruptura respecto a diferentes tipos y rangos de la autoridad. En palabras del autor

Los ataques de los Borbones contra la posición tradicional de la Iglesia al secularizar las parroquias y exigir a los curas que oficiaran sólo en español, la consolidación de vales (la ley de Consolidación de 1804, por la que el gobierno real exigía los vales - derechos de retención - que tenía la Iglesia sobre propiedades reales) y la sustitución del cura como maestro por maestros laicos en las nuevas escuelas primarias - parte de una serie de medidas generales para reforzar el poder de la Corona - pueden en realidad haber debilitado la legitimidad del Estado a los ojos de los campesinos al destrozar las

\footnotetext{
${ }^{27}$ Los franciscanos de Jalisco obtuvieron sucesivas autorizaciones para retener sus parroquias hasta 1798 cuando la secularización se generalizó. TAYLOR William. Bandolerismo e insurrección. Agitación social en el centro de Jalisco, 1790-1816. In: KATZ, F. Revuelta, rebelión y revolución. La lucha rural en México del siglo XVI al siglo XX. México: Era, 1990, p. 187-223.
} 
REVISTA DE HISTÓRIA

SÃO PAULO, N ${ }^{\circ} 169$, p. 145-180,

JULHO / DEZEMBRO 2013
María Elena Barral

La Iglesia católica en Iberoamérica: las instituciones locales en una época de cambios (siglo XVIII)

expectativas locales y acostumbradas respecto del párroco y amenazar con retirarlo del centro de la vida comunitaria. ${ }^{28}$

La vida de los párrocos y de las parroquias fue objeto del afán homogeneizador de la monarquía vertical. Otras disposiciones colaboraban en la misma dirección: se estableció un mismo arancel para el pago de los servicios religiosos, la restricción del espectro de mano de obra sujeta a las órdenes de los párrocos y el control de las festividades consideradas "dispendiosas" (tanto por el intento de instaurar una piedad más austera como por evitar el desvío de cualquier flujo de ingresos hacia España). Los párrocos, en este nuevo contexto, fueron fiscalizados en sus tareas, se insistió en su residencia en la parroquia y en la pronta y eficaz administración de sacramentos.

El impacto del arancel de 1767 en la Arquidiócesis de México venía a modificar una situación de pérdida de vigencia de sucesivas publicaciones de enmiendas y reelaboraciones del arancel de misas, entierros $y$ otros ministerios espirituales y el imperio de la práctica de la costumbre y el convenio, y de acuerdos que mezclaban pagos en efectivo, en especie y en servicios personales. ${ }^{29}$ Hasta entonces ni todos cobraban los mismos aranceles, ni todos promovían las mismas fiestas. El nuevo arancel buscaba instaurar "reglas fijas" y quizás este haya sido el aspecto más irritante, incluso más que los cambios que establecían en cuanto a sus montos. El nuevo arancel pretendía eliminar "la confusión de las costumbres".

Si las disposiciones del nuevo arancel fueron resistidas por parte de los párrocos y pueden incluso haber enajenado la lealtad a la Corona, muchos pueblos de indios - por el contrario - recurrieron a él como recurso frente a los abusos de los curas doctrineros. Lo entendieron como suyo y, en general, lo utilizaron para oponerse a los servicios personales de los indios exigidos por parte de los curas. La ocasión era propicia además para sumar nuevas denuncias sobre las deficiencias en la administración de sacramentos, el maltrato físico y verbal por parte de los eclesiásticos y la ausencia en ellos de un espíritu caritativo.

En Chayanta - Alto Perú - los cambios en la normativa sobre las contribuciones de las comunidades indígenas al clero dieron lugar a intensos enfrentamientos. El nuevo arancel eclesiástico, cuya sanción se anunció para

\footnotetext{
${ }^{28}$ TAYLOR, William. Bandolerismo e insurrección, op. cit., 1990, p. 212-213.

${ }^{29}$ TAYLOR, William. Ministros de lo sagrado: sacerdotes y feligreses en el México del siglo XVIII. ZamoraMichoacán: Colegio de Michoacán-Secretaría de Gobernación-El Colegio de México, 1999.
} 
REVISTA DE HISTÓRIA

SÃO PAULO, N 169 , p. 145-180,

JULHO / DEZEMBRO 2013
María Elena Barral

La Iglesia católica en Iberoamérica: las instituciones locales en una época de cambios (siglo XVIII)

este corregimiento a fines de 1770, ponía en cuestión tanto la magnitud de los bienes y servicios campesinos demandados por los párrocos como su naturaleza coercitiva o voluntaria. ${ }^{30}$ Las nuevas disposiciones limitaban algunas antiguas prácticas como la asignación de dinero o alimentos para las fiestas. ${ }^{31}$ Pero su cumplimiento se presentaba como una tarea extremadamente difícil porque los curas hacían una lectura muy laxa y autocomplaciente del nuevo arancel y en general se negaban a cumplir la nueva normativa amparados en ocasiones por el arzobispo.

Las comunidades indígenas hicieron lo propio y asumieron selectivamente la normativa: tomaban la eliminación de los aspectos abusivos de las cargas coloniales y conservaban los aspectos consensuales de las costumbres. En el caso de las fiestas rehusaron entregar las contribuciones acostumbradas rechazando sus costos económicos pero no las fiestas mismas. Como lo plantea Serulnikov "Invirtiendo los argumentos del clero, los indios consideraban que era su derecho la participación en los festivales católicos y una obligación de los párrocos el observarlos". ${ }^{32}$ Estas festividades - y sobre todo la participación de los alféreces en las mismas - fueron el lugar donde las religiones andinas pudieron sobrevivir y recrearse. Cuando los curas las suspendían, como consecuencia de la negativa de los indios a contribuir como lo habían hecho hasta entonces, las comunidades indígenas perdían algunos de sus espacios de afirmación y recreación de sus identidades. ${ }^{33}$

De cualquier manera tanto por el lado de las comunidades indígenas como por el lado de los curas lo que seguía en pie era una interpretación arbitraria y diversa de la normativa y de este modo a una "lucha abierta por el significado de las nuevas ordenanzas". ${ }^{34}$ Frente a la negativa de los curas por aplicar el nuevo arancel los indios recurrieron una y otra vez a los tribunales coloniales. Como en el caso señalado de México estas disputas derivarían en protestas más amplias en las cuales los campesinos indios cuestionaban colectivamente a las elites rurales.

\footnotetext{
${ }^{30}$ SERULNIKOV, Sergio. Conflictos sociales e insurrección en el mundo colonial andino. El norte de Potosí en el siglo XVIII. México: FCE, 2006.

${ }^{31}$ En los Andes esta práctica de ofrecer bienes - sobre todo alimentos - en las fiestas se denominaba ricuchicu.

32 SERULNIKOV, Sergio. Conflictos sociales, op. cit., 2006, p. 198.

${ }^{3}$ El análisis de Serulnikov va más allá de las cuestiones aquí señaladas y busca mostrar el modo en que las comunidades indígenas aprovecharon la disensión interna dentro de la administración colonial.

${ }^{34}$ SERULNIKOV, Sergio. Conflictos sociales, op. cit., 2006, p. 203.
} 
REVISTA DE HISTÓRIA

SÃO PAULO, N ${ }^{\circ} 169$, p. 145-180,

JULHO / DEZEMBRO 2013
María Elena Barral

La Iglesia católica en Iberoamérica: las instituciones locales en una época de cambios (siglo XVIII)

Un tipo de contestación que persiste cuando en el área andina se busca poner en práctica la secularización de las doctrinas en la década de $1750 .{ }^{35}$ Allí, el retiro de los religiosos de las parroquias de indios se inscribe visiblemente en la dinámica de los enfrentamientos que venimos de describir y que, en esta región, no sólo no era nueva sino que llevaba siglos.

Así, en el proceso de secularización de doctrinas en la Audiencia de Quito estudiado por Sabrina Guerra Moscoso el retiro de los religiosos de algunas doctrinas administradas por los dominicos del corregimiento de Latacunga y Riobamba ${ }^{36}$ se presenta como la consecuencia directa de las prácticas abusivas de los curas en materia de apropiación de mano de obra indígena, de usura, de cobro de estipendios o de acaparamiento de tierras. ${ }^{37}$

Estas prácticas de apropiación de recursos por parte de los eclesiásticos - y la competencia por los mismos al interior de la elite de poder local - se registra en las doctrinas de indios del Alto Perú desde el temprano período colonial y durante todo el siglo XVIII. ${ }^{38}$ Una de sus formas era la "mita de confesión"39 - penas de trabajo para cumplir las penitencias ordenadas en confesión - y el ricuchicu mencionado más arriba. Era muy frecuente la utilización indebida de mano de obra por parte del cura y la alteración del destino de la cuota legal de mano de obra que le correspondía como cura doctrinero al orientar el trabajo de los feligreses indios hacia sus propias producciones agrícolas o textiles, prohibidas, al menos, en teoría.

En otras dos regiones de Iberoamérica se puede verificar la centralidad de la parroquia como dispositivo privilegiado de encuadramiento social a lo largo del siglo XVIII. Se trata de dos regiones - Minas Gerais y Buenos Aires -

\footnotetext{
35 NAJAS, Rosemarie Terán. La Iglesia en los Andes en el siglo XVIII. Historia de la América Andina: el sistema colonial tardío, v. 3. Quito: UASB, 2001, p. 183-214.

${ }^{36}$ En el caso de Guano el remplazo de los frailes provocó un "tumulto" de los indios de la doctrina.

${ }^{37}$ MOSCOSO, Sabrina Guerra. La disputa por el control de las doctrinas en la Real Audiencia de Quito: Un estudio microhistórico sobre la tensión entre y dentro del Estado, la Iglesia y las redes de poder local. Guano, siglo XVIII. Tesis doctoral, Universitat Jaume I, Castellón (España), 2008.

${ }^{38}$ RODRÍGUEZ, Antonio Acosta. Los clérigos doctrineros y la economía colonial (Lima 1600-1630). Allpanchis, v. 16, n 19. Cusco, 1982, p. 117-150; LAVALLE, Bernard. Las doctrinas de indígenas como núcleos de explotación colonial (siglos XVI-XVIIl). Allpanchis, v. 16, n 19. Cusco, 1982, p. 151-171. HÜNEFELDT, Christine. Comunidad, curas y caciques hacia fines del período colonial: ovejas y pastores indomados en el Perú. HISLA, n² 2, 1983, p. 3-31. Un trabajo mucho más reciente que aborda específicamente el tema para el Alto Perú: ROBINS, Nicholas. Comunidad, clero y conflicto. Las relaciones entre la curia y los indios en el Alto Perú, 1750-1780. La Paz: Plural, 2009.

${ }^{39}$ Se trataba de una nueva adaptación de la mita colonial aplicada al ámbito eclesiástico. En este caso - como en el de la mita minera - también se ponía de manifiesto el carácter forzado de la prestación en la medida que se trataba de una modalidad de cumplimiento de una penalidad.
} 
REVISTA DE HISTÓRIA

SÃO PAULO, N 169 , p. 145-180,

JULHO / DEZEMBRO 2013
María Elena Barral

La Iglesia católica en Iberoamérica: las instituciones locales en una época de cambios (siglo XVIII)

que experimentan procesos de institucionalización en las décadas centrales de esta centuria ligados a transformaciones más amplias de colonización interna o de incorporación de "nuevas tierras" al dominio colonial. La construcción de un orden institucional en ambas regiones, pese a las diferencias notables de contextos, se basó en gran medida en estas estructuras de poder eclesiástico. ${ }^{40}$

Por un lado Minas Gerais atraviesa durante el siglo XVIII el ciclo del oro por lo cual desde los primeros años la Corona portuguesa se abocó a la organización administrativa de este espacio - capitanía desde 1720 y diócesis desde 1745 - con la creación de parroquias y la fundación de villas. Claudia Damasceno Fonseca ha estudiado sistemáticamente la "conversión" de Minas Gerais en un doble sentido: por un lado como cristianización de espacios ocupados por pueblos "paganos" y por el otro - aunque íntimamente ligado al anterior - a su transformación en territorios controlados por autoridades religiosas y civiles.

Este proceso de constitución - material e institucional - de los territorios urbanos en Minas Gerais durante el siglo XVIII reconoce en la red parroquial una de las primeras manifestaciones de la presencia real y de control social sobre la población que allí se encontraba. Las parroquias contribuyen de manera decisiva a "convertir" los sertões y las sus sedes pueden verse a la vez como signo y como condición necesaria de este proceso de institucionalización, en la medida que suponen la existencia de un núcleo de poblamiento estable y de cierto grado de prosperidad. Damasceno Fonseca reconoce diferentes fases en este proceso que se diferencian entre sí en función de las características de los agentes que intervinieron como del tipo de instrumentos institucionales de los cuales se sirvió.

\footnotetext{
${ }^{40}$ Para el caso de Brasil (Minas Gerais) puede verse FONSECA, Claudia Damasceno. Des terres aux villes de l'or. Pouvoirs et territoires urbains au Minas Gerais (Brésil, XVIII siècle). Paris: Publications du Centre Culturel Calouste Gulbenkian, 2003 y FONSECA, Claudia Damasceno. Freguesias e capelas. In: FEITLER, Bruno y SOUZA, Evergton Sales. (org.). A Igreja no Brasil: Normas e práticas durante a vigência das Constituições Primeiras do Arcebispado da Bahia. São Paulo: Editora Unifesp, 2011, p. 425-452. Para Buenos Aires puede verse: BARRAL, María Elena y FRADKIN, Raúl. Los pueblos y la construcción de las estructuras de poder institucional en la campaña bonaerense (1785-1836). Boletín del Instituto de Historia Argentina y Americana "Dr. Emilio Ravignani", ${ }^{\circ} 27$, 2005, p. 7-48; BARRAL, María Elena. De sotanas por la pampa. Religión y sociedad en Buenos Aires rural tardocolonial. Buenos Aires: Prometeo Libros, 2007; BARRAL, María Elena. Las parroquias del suroriente entrerriano a fines del siglo XVIII: los conflictos en Gualeguay. In: POLIMENE, P. (coord.). Autoridades y prácticas judiciales en el Antiguo Régimen. Problemas jurisdiccionales en el Río de la Plata, Córdoba, Tucumán, Cuyo y Chile. Rosario: Prohistoria, 2011, p. 95-115; BARRAL, María Elena. Alboroto, ritual y poder en los procesos de institucionalización de un área periférica del litoral rioplatense (Gualeguay, fines del siglo XVIII). Fronteras de la historia, v. 17-2/2012, p. 129-158.
} 
REVISTA DE HISTÓRIA

SÃO PAULO, N ${ }^{\circ} 169$, p. 145-180,

JULHO / DEZEMBRO 2013
María Elena Barral

La Iglesia católica en Iberoamérica: las instituciones locales en una época de cambios (siglo XVIII)

En la primera fase (1700-1720) quienes llevaron a cabo la explotación aurífera estaban obligados a garantizar a través de sus propios medios la "asistencia espiritual", de modo que los oficios religiosos tenían lugar en capillas efímeras y altares portátiles y poco a poco algunas de estas parroquias móviles dejaron de serlo y comenzaron a fijar sus sedes al adquirir algunos poblados mayor estabilidad. En estos primeros años los agentes eclesiásticos provenían del clero secular y el regular y, en particular, los religiosos - a menudo en misiones apostólicas - adquirieron una muy mala reputación por su afán desmedido de enriquecimiento. Esta información lejos de ser subestimada por las autoridades civiles fue tomada en cuenta para limitar progresivamente su participación y para finalmente prohibir la instalación de conventos. Si bien en esta primera fase se puso en funcionamiento la recolección del diezmo (que permitió en parte sostener el culto) no fue hasta la segunda fase (1721-1752) cuando la Corona comenzó a financiar en gran medida la construcción de parroquias y el sostenimiento del clero. En 1724 el rey instituyó las primeras veinte parroquias coladas (de institución real) de Minas Gerais que en general correspondían a las localidades más importantes desde el punto de vista de su peso económico y demográfico (y ocho de ellas ya eran villas). ${ }^{41} \mathrm{Su}$ institución asimismo estaba ligada a la necesidad de reorganizar el territorio y replantear los mecanismos de control luego de las rebeliones que tuvieron lugar en estos años. A partir de este momento coexistieron las parroquias coladas y encomendadas (o de institución episcopal) o curatos. Luego de 1752 disminuyó sensiblemente la intervención real en la conformación de la red eclesiástica y sólo el 24,1\% de los curatos se convirtieron en parroquias coladas. En contraste en la segunda mitad del siglo XVIII con la crisis minera y la expansión de la frontera agrícola aumentaría un tipo de estructura eclesiástica como las capillas sucursales, muchas de las cuales aspiraban a convertirse en sede parroquial.

Resulta interesante observar como en el caso de la diócesis de Mariana el período de mayor sostenimiento del culto por parte de la Corona no se corresponde el período más decididamente regalista. En esta región la dinámica de la economía condicionó un tipo de configuración eclesiástica que vio incrementar las capillas de la frontera agrícola en desmedro de las parroquias coladas, es decir aquellas con párrocos sostenidos por la Corona.

\footnotetext{
${ }^{41}$ Entre fines del siglo XVII hasta 1752 el 75\% de las parroquias creadas por los obispos en el territorio de la capitanía se convierten en parroquias remuneradas ("coladas") por el rey de Portugal.
} 
REVISTA DE HISTÓRIA

SÃO PAULO, N 169 , p. 145-180,

JULHO / DEZEMBRO 2013
María Elena Barral

La Iglesia católica en Iberoamérica: las instituciones locales en una época de cambios (siglo XVIII)

Por último, en la experiencia de poblamiento e institucionalización de Minas Gerais durante el siglo XVIII, el clero regular estuvo prácticamente ausente. El sostenimiento de la vida religiosa fue compartido por el rey, los obispos, el clero secular y en gran medida por las cofradías responsables de la construcción y ornamentación de iglesia y de la remuneración de los sacerdotes y sobre las que volveremos más adelante. En los campamentos efímeros de los mineros de comienzos del siglo XVIII, como en los poblados agrícolas o los presidios/fuertes fundados en las zonas de frontera los párrocos fueron, con frecuencia, la primera y principal forma de autoridad.

En el extremo sur de Hispanoamérica las zonas rurales de Buenos Aires experimentarían un proceso parecido en relación al rol fundante de las parroquias en el armado institucional y de los párrocos como autoridades de un poder institucional.

La región experimentó un importante crecimiento durante la segunda mitad del siglo XVIII, constituyéndose Buenos Aires en capital del Virreinato del Río de la Plata en 1776 e impulsando el poblamiento y crecimiento del hinterland rural. El despliegue de las instituciones y estructuras eclesiásticas en la región comienza con la creación de la diócesis de la Santísima Trinidad del Puerto de Buenos Aires en 1620 con su sede episcopal en la ciudad de Buenos Aires pero pasaría más de un siglo desde la creación del obispado para que comenzara a la instalación de los primeros curatos rurales en Buenos Aires en 1730.

Esta estructura diocesana originaria sufrió a lo largo del siglo XVIII y comienzos del XIX, transformaciones en dirección a la multiplicación de sedes de poder eclesiástico. El mayor despliegue de las estructuras eclesiásticas se verifica en 1780. Desde 1806 comenzaba la incorporación de algunos fuertes de la línea de frontera - que contaban con capilla y capellán castrense - a la estructura diocesana como parroquias o viceparroquias. Este proceso se consolidó en 1825 cuando todos los fuertes de la antigua frontera se transformaron en parroquias o viceparroquias. Al comparar la evolución de las estructuras de poder institucional eclesiásticas y a su personal como las estructuras y agentes de poder judicial/policial y militar/miliciana resulta evidente que durante las décadas centrales del siglo XVIII la presencia eclesiástica fue preponderante y la designación de alcaldes de hermandad siguió los pasos trazados por la estructura parroquial. ${ }^{42}$

${ }^{42}$ BARRAL, María Elena y FRADKIN, Raúl. Los pueblos, op cit., 2005. 
REVISTA DE HISTÓRIA

SÃO PAULO, N ${ }^{\circ} 169$, p. 145-180,

JULHO / DEZEMBRO 2013
María Elena Barral

La Iglesia católica en Iberoamérica: las instituciones locales en una época de cambios (siglo XVIII)

El papel de las parroquias en otra región de la diócesis muy cercana a la ciudad de Buenos Aires - el sudeste de Entre Ríos a fines del siglo XVIII - muestra algunas diferencias con aquel primer proceso de despliegue de la red parroquial en Buenos Aires de $1730 .{ }^{43}$ En primer lugar porque allí la instalación de las parroquias a inicios de la década de 1780 se organizó en un contexto muy diferente al que medio siglo antes registró la creación de las primeras parroquias de la campaña bonaerense. En las zonas rurales de Buenos Aires los párrocos fueron para muchos hombres y mujeres la primera - y tal vez la única - autoridad de un poder institucional conocida a lo largo de su vida, mientras que en Entre Ríos los párrocos se encontraron con mayores resistencias al momento de ejercer su autoridad. ${ }^{44}$ Por un lado porque había autoridades - judiciales, policiales y militares - previas y, además, porque el proceso de institucionalización en la región se aceleró por inmediata la instalación de los cabildos y las comandancias militares ${ }^{45}$ en el marco de un "experimento borbónico" de fundación de villas como parte de una estrategia defensiva. En consecuencia en esta región, el papel "fundacional" de las parroquias fue mucho menos evidente dado que pocos años después de su creación, debieron convivir con los cabildos y las comandancias militares. Los párrocos se encontraban lejos de haber asegurado la obediencia de sus feligreses cuando ya se hallaron rodeados de otras autoridades institucionales que buscaban encuadrar su acción. ${ }^{46}$

Es evidente que estos párrocos se encontraron desempeñando sus funciones en un período de fuerte fiscalización de sus funciones y, en algunos casos, en zonas atravesadas por una serie de tensiones que en la campaña de Buenos Aires no se registran para los mismos años. Estas tensiones tienen que ver con la competencia por los recursos entre pobladores y hacendados y también por otro tipo de recursos disputados en distintos terrenos. En esta región se registra una intensa conflictividad entre pequeños propietarios y

\footnotetext{
43 BARRAL, María Elena. De sotanas por la pampa, op. cit., 2007.

${ }^{44}$ BARRAL, María Elena. Las parroquias del suroriente entrerriano, op. cit., 2001, y BARRAL, María Elena. Alboroto, ritual, op. cit., 2012.

${ }^{45}$ DJENDEREDJIAN, Julio. Economía y sociedad en la Arcadia criolla. Formación y desarrollo de una sociedad de frontera en Entre Ríos, 1750-1820. Tesis de doctorado, Universidad de Buenos Aires (Argentina), 2003.

${ }^{46}$ Los cabildos desempeñaron en esta región un importante papel en la búsqueda por el control de los recursos debido a que por largo tiempo fueron quienes otorgaron tierras, aun a título precario. Esta posibilidad - así como la de crear cuerpos de milicias - convirtió a los ayuntamientos en cajas de resonancia de los conflictos locales y habilitó la conformación de ámbitos de influencia, de "clientelas" y de facciones que buscaban obturar el acceso de las contrarias a los puestos de los cabildos. DJENDEREDJIAN, Julio, Economía y sociedad, op. cit., 2003.
} 
REVISTA DE HISTÓRIA

SÃO PAULO, N 169 , p. 145-180,

JULHO / DEZEMBRO 2013
María Elena Barral

La Iglesia católica en Iberoamérica: las instituciones locales en una época de cambios (siglo XVIII)

ocupantes de tierras y grandes comerciantes porteños en busca de tierras; conflictos jurisdiccionales por el control político y conflictos fronterizos con dominios de Portugal. Los párrocos, en este contexto vieron cuestionada, e incluso impugnada, su autoridad. En cada una de las villas es posible reconocer intensos conflictos en los tramos iniciales de este proceso de institucionalización que involucraron a eclesiásticos en sus diversas funciones o posiciones.

Así las autoridades religiosas, al tiempo que intervinieron activamente en la lucha facciosa por la apropiación de recursos, se presentaron como dominios desde los cuales obtener atribuciones y competencias - y sobre todo legitimidad - en las disputas locales. La intervención de las instituciones, autoridades y contenidos religiosos en este proceso fue muy variada y creativa. Entre ellas se encuentran el alcance de las jurisdicciones parroquiales o de las sedes religiosas como medios para asegurar el acceso a la tierra o a la expectativa de su reparto; los cargos asociados a la gestión religiosa como modo de obtener privilegios (por ejemplo los mayordomos de fábrica y limosneros podían eximirse del servicio de armas) y el papel de los rituales religiosos en la lucha política local (como el uso del Santísimo Sacramento en un acto de destitución de la autoridad religiosa frente a la autoridad civil).

Los ejemplos referidos de las parroquias como instituciones de encuadramiento social, sus reformulaciones y diferentes sentidos otorgados por los agentes implicados muestran a la vez su enorme plasticidad y versatilidad y la notable eficiencia demostrada en muy diversos contextos de institucionalización. Estos dos rasgos, probablemente pueden construir una relación de causalidad y una explicación. Sólo un tipo de organización que presente estas posibilidades de adaptación y la voluntad de los sujetos intervinientes de dotarlas de diversos sentidos puede sobrevivir a épocas y experiencias históricas tan diversas. Algo parecido ha sucedido con las cofradías. La segunda parte de este trabajo busca hacer dialogar un conjunto de trabajos sobre las cofradías y las hermandades religiosas en esta dirección.

\section{Las cofradías: nuevos sentidos para viejas instituciones}

En las páginas anteriores mencionábamos cómo algunas de las comunidades indígenas de México respondieron a la secularización de parroquias recurriendo a las cofradías, a sus capillas y a sus bienes como modo de preservar la dificultosa organización de sus estrategias económicas y de sus creencias. Esto era posible debido a la vitalidad de las cofradías coloniales y a las variadas y paradojales funciones que desempeñaron y significados que permitieron desplegar. A su dinamismo se debe también que el real 
REVISTA DE HISTÓRIA

SÃO PAULO, N ${ }^{\circ} 169$, p. 145-180,

JULHO / DEZEMBRO 2013
María Elena Barral

La Iglesia católica en Iberoamérica: las instituciones locales en una época de cambios (siglo XVIII)

decreto de consolidación de vales reales las afectara directamente. Entre las instituciones eclesiásticas que debían desprenderse del dinero líquido y de los bienes raíces y capitales de inversión para ser depositados en la Tesorería Real se encontraban las cofradías. ${ }^{47} \mathrm{~A}$ la hora de obtener recursos la Corona sabía adónde recurrir.

Pero incluso antes, desde mediados del siglo XVIII las cofradías comenzaron a ser fiscalizadas más de cerca por las autoridades coloniales y se les exigió la puesta en forma de sus cuentas y de sus constituciones o estatutos que, al menos en teoría, debían ser aprobadas por el obispo y en ocasiones confirmadas por bula papal. La mayor parte de la información disponible sobre estas hermandades proviene precisamente del siglo XVIII, cuándo aumentó la fiscalización de sobre ellas y se exigió la puesta en forma de sus constituciones y de sus cuentas. A partir de 1750 la reorganización eclesiástica las afectó de diferentes maneras: por un lado se impulsó una mayor uniformidad, la reducción de su número y una mayor eficiencia en su gestión. ${ }^{48}$

En efecto, muchas de estas hermandades, tanto en Hispanoamérica como en Brasil, funcionaban sin tener sus constituciones aprobadas - y en muchos casos sin contar siquiera con un esbozo de las mismas - lo que muestra el importante margen de autonomía con que funcionaban. Este tipo de situaciones eran las que se volvieron intolerables de forma creciente en el transcurso del siglo XVIII para los monarcas, sus ministros y funcionarios coloniales.

El control sobre las cofradías no era una tarea sencilla. En primer lugar eran muy numerosas. Únicamente para el arzobispado de Guatemala se calculan entre 2.000 y 3.000 cofradías de indios hacia fines del siglo XVII y sólo en Chiapas se contaban 282 cofradías en 84 pueblos de indios, es decir entre 3 y 4 cofradías por poblado. ${ }^{49}$

Pero además estas instituciones han mostrado su variablidad en relación a su composición étnica y por eso es posible encontrar hermandades de blancos - con excluyentes requisitos de limpieza de sangre que seleccionaban a sus miembros - las mencionadas de indios, de negros libres y/o esclavos, de mestizos o multiétnicas. Para mencionar algunas formas de agrupamiento puede verse como las cofradías del Santísimo Sacramento

\footnotetext{
${ }^{47}$ WOBESER, Gisela von. Dominación colonial; la consolidación de vales reales en Nueva España, 1804-1812. México: Unam, 2003.

${ }^{48}$ MANCUSO, Laura. Cofradías mineras: religiosidad popular en México y Brasil, siglo XVIII. México: El Colegio de México, 2007.

49 RUZ, Mario Humberto. Una muerte auxiliada. Cofradías y hermandades en el mundo maya colonial. Relaciones, v. 24, nº 94. Zamora/México: Colegio de Michoacán, 2003, p. 19-58.
} 
REVISTA DE HISTÓRIA

SÃO PAULO, N 169 , p. 145-180,

JULHO / DEZEMBRO 2013
María Elena Barral

La Iglesia católica en Iberoamérica: las instituciones locales en una época de cambios (siglo XVIII)

agrupaban a los blancos y notables de las ciudades o aldeas, las del Rosario a los negros (libres o esclavos) y las dedicadas a las Ánimas del Purgatorio se encontraban ampliamente extendidas y muchas de ellas permitían el acceso de indios y mestizos. Intervenían activamente en la vida religiosa de las ciudades, de los pueblos de indios y de las áreas rurales más mestizadas en los tiempos fuertes del calendario litúrgico como la Semana Santa y la Pascua o el Corpus Christi y también en sus celebraciones particulares.

Si su principal objetivo era devocional - el culto a una virgen o a un santo, la iluminación del Santísimo Sacramento, el rezo del rosario o el sufragio de las almas del Purgatorio - también se las ha analizado como elementos organizativos "que otorgaban a ciertos grupos de la población un lugar de encuentro, festividades comunes, proyectos de grupo, facilidades de ayuda mutua y espíritu de cuerpo"50 y de un tipo de organización con un papel decisivo en la configuración de las formas de religión local. ${ }^{51}$

Otros estudios han enfatizado su papel como dispositivo de integración adaptativa, en el contexto de la reconstrucción del mundo indígena luego de la conquista ${ }^{52}$ o como "organizaciones estrechamente vinculadas con la dinámica económica y social territorial", 53 participando de una articulación positiva con las tendencias regionales. Esto puede verificarse en el caso de las cofradías michoacanas - las que agrupaban a la élite indígena como las integradas por campesinos - en la medida que ocuparon un lugar central en la vida social y religiosa de las aldeas y por su capacidad para actuar con éxito como grupos económicos orientados hacia la ganancia dentro de la sociedad predominantemente criolla, logrando algunas de ellas adquirir una función interétnica y actuar como representantes sociales de las élites políticas y económicas de las poblaciones autóctona e inmigrante.

Además de su papel en las estrategias económicas de las comunidades, la integración de estas instituciones en el sistema de autoridad de las comunidades indígenas ha sido señalada para diferentes regiones. Y su presencia sobresale cuando determinadas políticas afectaban los equilibrios de las instituciones comunales (como la secularización de doctrinas, la apropiación

\footnotetext{
${ }^{50}$ LOCKHART, James. Organización y cambio social en la América española colonial. In: BETHELL, Leslie (ed.). Historia de América Latina, tomo 4. Barcelona: Crítica, 1990, p. 84.

${ }^{51}$ CHRISTIAN, Williams. Religiosidad local en la España de Felipe II. Madrid: Nerea, 1991.

${ }^{52}$ CELESTINO, Olinda y MEYERS, Albert. Las cofradías en el Perú: región central. Frankfurt-Main: Verlag Klaus DieterVervuert, 1981.

53 BECHTLOFF, Dagmar. La formación de una sociedad intercultural: Las cofradías en el Michoacán colonial. Historia Mexicana, v. 43, n² 2, 1993, p. 251-263.
} 
REVISTA DE HISTÓRIA

SÃO PAULO, N ${ }^{\circ} 169$, p. 145-180,

JULHO / DEZEMBRO 2013
María Elena Barral

La Iglesia católica en Iberoamérica: las instituciones locales en una época de cambios (siglo XVIII)

de recursos de las cajas de comunidad e incluso las campañas de extirpación de las idolatrías). Las cofradías habrían así replicado las instituciones "civiles" reforzándolas y suplantándolas en momentos de debilidad. ${ }^{54}$

Asociaciones religiosas con fines devocionales, dispositivos de integración adaptativa, espacios de socialización, formas de ejercicio de la autoridad o instrumentos de supervivencia de las economías indígenas. Sin duda se trata de instituciones complejas. La intransigencia de los funcionarios borbónicos para introducir las reformas se replicó en el terreno religioso y no dejó de tener consecuencias como veremos en seguida para el caso de Nueva España.

En los pueblos de indios novohispanos los bienes de comunidad se confundían con los bienes de cofradía al punto que por ejemplo en Zacatecas "cofradía", "pueblo" y comunidad de residencia tenían una correspondencia casi exacta. ${ }^{55}$ En Jalisco (Nueva España) a mediados del siglo XVIII casi todas las cofradías en los pueblos de indios contaban con ganado, tierras y dinero en efectivo. Algunas tenían casas y almacenaban el grano cosechado en pequeñas labores consagradas a la virgen y su producto servía para pagar el tributo, el costo de los litigios o para medidas de emergencia.

En las últimas décadas del siglo XVIII los funcionarios borbónicos informaban con preocupación a los virreyes que las autoridades indígenas estaban "pasando" tierra y ganado a las cofradías o que estas asociaciones habían recibido terrenos, animales y dinero cuyo origen era desconocido: se "desnombraban" los bienes de comunidad y para "aplicarlos" a las cofradías. ${ }^{56}$ De este modo buscaban detener la sangría de las cajas de la comunidad transfiriendo a las cofradías algunos de sus bienes. Se trataba de una estrategia para evadir la voracidad de las autoridades coloniales y consistía en transferir los ingresos de las primeras a las segundas como modo de burlar las exacciones coloniales en aumento durante las décadas borbónicas. Los indígenas realizaban esta transferencia porque en las cofradías tenían, hasta el momento, más autonomía para determinar el destino de sus fondos (por ejemplo para las celebraciones religiosas).

Las mismas medidas se planteaban apartar al clero del manejo de las cofradías como modo de fomentar las cajas de comunidad, fortalecer la au-

\footnotetext{
${ }^{54}$ VEGA, Walter. Cofradías en el Perú colonial: una aproximación bibliográfica. Diálogos, $\mathrm{n}^{\circ} 1$, 1999, p. 137-152.

${ }_{55}$ MANCUSO, Laura. Cofradías mineras, op. cit., 2007.

${ }^{56}$ ESTRADA, Dorothy Tanck de. Pueblos de indios y educación en el México colonial, 1750-1821. México: El Colegio de México, 2000.
} 
REVISTA DE HISTÓRIA

SÃO PAULO, N 169 , p. 145-180,

JULHO / DEZEMBRO 2013
María Elena Barral

La Iglesia católica en Iberoamérica: las instituciones locales en una época de cambios (siglo XVIII)

toridad real y acceder a la riqueza comunitaria. Desde la vigencia de estas medidas los rebaños de las cofradías de indios se redujeron notablemente.

Si en algunas regiones iberoamericanas las cofradías se debilitaban, en contraste, en otras zonas, desempeñaron un rol decisivo en el sostenimiento y recreación de la vida religiosa. En la diócesis de Mariana (Minas Gerais) esta visibilidad y fuerte intervención se debió en gran medida a la ausencia de las órdenes religiosas. En efecto, desde las primeras décadas del siglo XVIII las órdenes religiosas tenían prohibido su ingreso como medida preventiva frente al apetito desmedido demostrado por algunos frailes en los momentos iniciales de incorporación de la región al dominio colonial. La decisión de impedir su instalación se daba en un momento de fuerte consenso en torno a la necesidad de reforma y control del clero regular y podría interpretarse, muy libremente, como la versión lusitana de la secularización de las parroquias.

Así, en Minas Gerais el impulso a determinadas devociones como la Virgen del Carmen, de la Merced o Nuestra Señora del Rosario, por ejemplo, estuvieron a cargo de las cofradías, es decir de las elites locales y demás grupos que las integraban. De este modo las hermandades y terceras órdenes jugaron un rol decisivo en la vida social de esta región al punto que la presencia de varias de ellas en una localidad puede reflejar su importancia demográfica. ${ }^{57}$ Resulta interesante, además, pensar a estas terceras órdenes como una presencia de los regulares mediatizada por laicos ya que desde el punto de vista de su funcionamiento su erección dependía de la aprobación de los provinciales y generales y sus miembros debían cumplir con la regla que correspondiera. ${ }^{58}$

En la diócesis de Mariana a fines de la época colonial existían 234 cofradías y terceras órdenes y casi un centenar de las mismas (93) tenían su capilla en una sede propia diferente de la parroquial. Algunas de las capillas de las cofradías contaban con edificios sólidos y bien ornamentados y contrastaban con las iglesias parroquiales (89 para la misma época) algunas de las cuales se encontraban en muy mal estado de conservación al punto que los obispos en ocasiones trasladan las sedes de las parroquias a las iglesias de las cofradías. ${ }^{59}$ Aquí puede verse una situación parecida a la señalada para Nueva España donde las sedes de las cofradías cobraron una importancia decisiva como espacios de congregación comunitaria en la medida que declinaban las parroquias que habían sido secularizadas. Es el caso de

\footnotetext{
FONSECA, Claudia Damasceno, Des terres, op. cit., 2003.

FONSECA, Claudia Damasceno, Des terres, op. cit., 2003, p. 95.

59 FONSECA, Claudia Damasceno. Des terres, op. cit., 2003, p. 403.
} 
REVISTA DE HISTÓRIA

SÃO PAULO, N ${ }^{\circ} 169$, p. 145-180,

JULHO / DEZEMBRO 2013
María Elena Barral

La Iglesia católica en Iberoamérica: las instituciones locales en una época de cambios (siglo XVIII)

la parroquia de Nuestra Señora de la Concepción de Rio das Pedras que debió trasladar su sede (y el Santísimo Sacramento) a la capilla de la cofradía del Rosario de los Negros. Como en toda Iberoamérica este tipo de cofradía integrada por negros estaba dirigida por blancos. Pese a ello este cambio de status es significativo y muestra cómo las capillas de las cofradías ofrecían una alternativa cuando las parroquias se encontraban en declive.

Como hemos visto para las áreas hispanoamericanas las cofradías se presentaron como espacios donde las poblaciones indígenas pudieron afirmar sus identidades étnicas. Las poblaciones afroamericanas de Brasil también encontraron en estas instituciones algunas respuestas en el marco de los procesos de reconstrucción de sus identidades "nacionales". En el caso de las hermandades de negros esclavos y/o libres de Pernambuco y Bahía pueden reconocerse las adscripciones correspondientes a las antiguas naciones de origen. ${ }^{60}$ Se trata de un tipo de adaptación creativa o - en los términos que propone Luiz Geraldo Silva - de la construcción de un self basado en aspectos étnicos y en la historia local. ${ }^{61}$ En este caso las hermandades religiosas proporcionaron un marco propicio para su desarrollo.

Las hermandades religiosas de negros de Bahía y Pernambuco muestran diferencias en relación a los criterios de reclutamiento y acceso a los cargos más altos en función de la composición étnica. ${ }^{62}$ En Pernambuco angolas o crioulos (negros nacidos en Brasil o mestizos) podían integrar las hermandades de negros indistintamente ya que en sus constituciones no había restricciones entre los negros nacidos en América o los provenientes de Angola o Costa de Mina (y los blancos si lo quisieran...). Sin embargo algunas de ellas en sus constituciones reservaban los cargos más importantes - rey/

\footnotetext{
${ }^{60}$ Mientras el origen mayoritario de la población esclava de la capitanía de Pernambuco provenía de la región Congo-Angola, en la segunda mitad del siglo XVIII en Bahía el mayor porcentaje provenía de Costa de Mina.

${ }^{61}$ Se trata de una investigación que busca explicar la pax pernambucana (en oposición a las distintas formas de resistencia verificadas en Bahía) y para lo cual analiza la composición étnica de la esclavitud en ambas regiones y el modo en que esas diferencias se expresan en las hermandades religiosas. SILVA, Luiz Geraldo. "Sementes da sediçao": etnia, revolta escrava e controle social na América portuguesa (1808-1817). Afro-Ásia, no 25-26, 2001, p. 9-60 y SILVA, Luiz Geraldo. Religião e identidade étnica. Africanos, crioulos e irmandades na América portuguesa. Cahiers des Amériques Latines, v. 44, 2003, p. 77-96.

${ }^{62}$ Entre los siglos XVII y XIX Patricia Mulvey encuentra 44 en Bahía y 20 en Pernambuco. Cit. en SILVA, Luiz Geraldo, "Sementes da sediçao", op. cit., 2001, p. 20.
} 
REVISTA DE HISTÓRIA

SÃO PAULO, N 169 , p. 145-180,

JULHO / DEZEMBRO 2013
María Elena Barral

La Iglesia católica en Iberoamérica: las instituciones locales en una época de cambios (siglo XVIII)

reina; juez/jueza - a los esclavos, negros libres crioulos o angolas (bantos). ${ }^{63}$ Como lo muestra Luis Geraldo Silva estas hermandades, con la compleja organización jerárquica que se revela en su interior, constituyeron importantes instrumentos de control social desde el punto de vista de las autoridades coloniales. Al mismo tiempo, desde la perspectiva del negro libre o cautivo, estas instituciones podían propiciar la emergencia de identidades y cohesión social.

En contraste, en Bahía hacia fines del siglo XVIII algunas hermandades contaban con criterios más exclusivos respecto al ingreso de algunos grupos. Es el caso de la Hermandad del Señor de los Martirios de la ciudad de Cachoeira - constituida "por los negros de la nación Gege" proveniente de la región de Costa de Mina - quienes no admitían a los negros nacidos en la América portuguesa "por las controversias que acostumbran tener semejantes hombres con los de la nación Gege". ${ }^{64}$ Al parecer la composición "sudanesa" de la esclavitud en Bahía se reflejaba cada vez con más fuerza en el universo de las hermandades religiosas.

Por su parte tanto en Rio de Janeiro como en Minas Gerais los franciscanos y los carmelitas promovieron un tipo de devociones centradas en santos negros y de origen africano y el establecimiento de hermandades para su culto como San Elesbão y Santa Efigenîa. Ellos se presentaban como ejemplos de virtudes cristianas y de modelos de santidad en un tipo de catequesis organizada para la conversión y cristianización de la población africana y de sus descendientes. ${ }^{65}$ La investigación de Anderson Machado de Oliveira demuestra el modo en que estos santos fueron asumidos como propios en el marco colectivo de las hermandades de negros en función de otra "pareja" venerada: Mawu y Lissa o la Luna y el Sol. Se trataba de una creencia en las divinidades creadoras sumamente importante del Reino de Dahomey, en la costa de Mina, de donde provenía la mayoría de los cofrades. ${ }^{66}$

\footnotetext{
${ }^{63}$ Estas figuras no eran sólo simbólicas ni ficticias y si en el siglo XVII fueron la mayoría esclavos, durante el siglo XVIII era necesario demostrar una posición social y económica más elevada: poseer algunos bienes, ser casado, y profundamente piadoso. En la mayoría de los casos se trataba de negros libres.

${ }^{64}$ SILVA, Luiz Geraldo. "Sementes da sediçao", op. cit., 2001, p. 22.

${ }^{65}$ OLIVEIRA, Anderson José Machado de. Devoção e identidades: significados do culto de Santo Elesbão e Santa Efigênia no Rio de Janeiro e nas Minas Gerais no Setecentos. Topoi, n 12, 2006, p. 60-115.

${ }^{66}$ En este caso la asociación entre los dos cultos estructurados en forma de pares parece haber estado favorecida por una asimilación - intencionada o no - entre ambos en una obra del fraile carmelita fr. José Pereira de Santana. OLIVEIRA, Anderson José Machado de. Devoção, op. cit., 2006, p. 66.
} 
REVISTA DE HISTÓRIA

SÃO PAULO, N ${ }^{\circ} 169$, p. 145-180,

JULHO / DEZEMBRO 2013
María Elena Barral

La Iglesia católica en Iberoamérica: las instituciones locales en una época de cambios (siglo XVIII)

La misma hermandad indicaba en sus constituciones cinco capítulos referidos a la creación de una folia, una suerte de danza con instrumentos, "mucho ruido, extravagancia y confusión". La folia preveía la creación de un Estado compuesto por un emperador, una emperatriz, un príncipe y una princesa y siete reyes. El Estado por un lado podía ser una instancia para la resolución de conflictos pero también podía evocar algunas estructuras políticas existentes en la Costa de los Esclavos de donde provenían los negros minas fundadores de la hermandad. En este caso la hermandad albergaba sin demasiadas mediaciones las instituciones de los reinos africanos en un tipo de relectura del catolicismo que realizaban los diversos pueblos africanos de la diáspora. Al mismo tiempo las hermandades conservaban una función importante de mediación "infrajudicial" y pacificación típica de las cofradías del mundo moderno de la vieja Europa. ${ }^{67}$ Tomás Mantecón Movellán ha estudiado el papel que asumieron las cofradías religiosas como instancias extrajudiciales en la resolución de conflictos en Cantabria. ${ }^{68}$ Se trataba de una dimensión de la confraternidad que abría un escape a la jurisdicción ordinaria por medio de mediaciones en conflictos concretos - "escándalos públicos" de índole moral o cuestiones que afectaban al colectivo de vecinos - tendentes a reequilibrar el orden que se sumaban a su acción pacificadora "regular" proporcionada a través de la organización de los ciclos festivos anuales.

Hemos mencionado la complejidad de estas instituciones en función de los diversos y en ocasiones contradictorios sentidos que permitieron desarrollar. Estas hermandades formaban parte de un tipo de institución-mediadora o institución-puente que hicieron posible la dominación colonial y también la organización de formas de resistencia o de "adaptación en re-

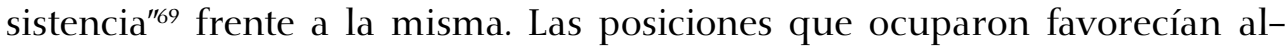
gunos desplazamientos: entre las normas y las prácticas, entre la religión prescripta y la observada o entre las instituciones de control y las formas de sociabilidad. Por lo mismo podían ser a su vez portadoras de mensajes de subordinación y de revolución. Incluso mensajes "enmasacarados" como el último ejemplo de una hermandad de negros en Buenos Aires que cierra

\footnotetext{
${ }_{67}$ Sobre la noción de infrajudicialidad e infrajusticia véase MOVELLÁN, Tomás Mantecón. El peso de la infrajudicialidad en el control del crimen. Etudis: Revista de Historia Moderna, $\mathrm{n}^{\circ} 28$, Universidad de Valencia, 2002, p. 43-75.

${ }^{68}$ MOVELLÁN, Tomás Mantecón. Contrarreforma y religiosidad popular en Cantabria. Las cofradías religiosas. Santander: Universidad de Cantabria, 1990.

${ }^{69}$ STERN, Stern. La era de la insurrección andina, 1742-1782: una reinterpretación. In: STERN, S. Resistencia, rebelión y conciencia campesina en los Andes. siglos XVIII al XX. Lima: IEP, 1990, p. 50-96.
} 
REVISTA DE HISTÓRIA

SÃO PAULO, N 169 , p. 145-180,

JULHO / DEZEMBRO 2013
María Elena Barral

La Iglesia católica en Iberoamérica: las instituciones locales en una época de cambios (siglo XVIII)

este incompleto recorrido por las experiencias históricas desplegadas en torno a algunas cofradías iberoamericanas.

En Buenos Aires durante el siglo XVIII la mayoría de los negros africanos o afrodescendientes pertenecía a alguna cofradía e incluso a varias. ${ }^{70}$ La Cofradía de San Baltasar y Ánimas funcionaba en la Iglesia de La Piedad de Buenos Aires. Según sus constituciones de 1772 podían ser admitidas "las personas de ambos sexos, así morenos, pardos e indios" y que "sepan la Doctrina Cristiana, sean de buena vida, y costumbres, sin nota de escandalosos, y el que no tuviere dichas calidades, no podrá ser admitido". ${ }^{71}$

Como puede verse en estas constituciones, a diferencia de las mencionadas de Bahía o Pernambuco, no había referencias a ningún criterio de reclutamiento en base a la pertenencia a naciones africanas de origen. Sin embargo es posible encontrarlas en un registro más oculto y entonces resulta verosímil imaginar que los lazos cofradiales hayan servido como vía para convocar a las expresiones más clandestinas en los cuales si se ponen en evidencia las adscripciones a naciones africanas como lo veremos enseguida en ocasión de la coronación de Pedro Duarte, mayordomo de la cofradía, como rey Congo. ${ }^{72}$

En principio la ceremonia se había desarrollado en forma clandestina y en ocasión del entierro de un cofrade difunto. La noticia salió a la luz por la disputa que tuvo lugar entre dos soldados de la Compañía de negros libres en la cual, al parecer uno de ellos "comisionado para recoger los negros fugitivos y gobernar los tambos de ellos" se negó a prestar ayuda para inspeccionar la "coronación". Y había cobrado gravedad porque la coronación de Duarte podía ser evaluada como un desafío abierto a la investidura del virrey y, por extensión, a Corona española, avivando los temores de una revuelta negra. Algunas declaraciones de los testigos y del mismo imputado transparentan estas pertenencias invisibles en otros textos. Joseph González, de oficio aguatero, informaba sobre Duarte "que sabe que el día que se hace la función de San Baltasar en la Iglesia de la Piedad lo respetan, y obedecen

${ }^{70}$ ROSAL, Miguel Ángel. Africanos y afrodescendientes en el Río de la Plata, siglos XVIII-XIX. Buenos Aires: Dunken, 2009.

${ }^{71}$ AGN, Periodo colonial. Gobierno. Justicia, IX-31-8-5, doc. 1365, cit. por CIRIO, Norberto Pablo. Antecedentes históricos del culto a San Baltazar en la Argentina: La Cofradía de San Baltazar y Animas (1772-1856). Latin American Music Review / Revista de Música Latinoamericana, vol. 21, $\mathrm{n}^{\circ}$ 2. Texas: University of Texas Press, 2000, p. 190-214: 195.

${ }^{72}$ CIRIO, Norberto Pablo. ¿Rezan o bailan? Disputas en torno a la devoción a san Baltazar por los negros en el Buenos Aires colonial. In: IV REUNIÓN CIENTÍFICA: MUJERES, NEGROS Y NIÑOS EN LA MÚSICA Y SOCIEDAD COLONIAL IBEROAMERICANA. Actas. Edit. par Víctor Rondón. Santa Cruz de la Sierra: Asociación Pro Arte y Cultura, 2002, p. 88-100. 
REVISTA DE HISTÓRIA

SÃO PAULO, N ${ }^{\circ} 169$, p. 145-180,

JULHO / DEZEMBRO 2013
María Elena Barral

La Iglesia católica en Iberoamérica: las instituciones locales en una época de cambios (siglo XVIII)

como a tal rey, de su nación, y no como a mayordomo". El mismo Duarte "natural de la nación conga" desmentía este testimonio "No ha ido al hueco con insignias de Rey, y solo fue con los de su nación con su capa y sombrero de una pollera, echó un quita sol, para que lo reconociesen por mayordomo pero no por Rey" ${ }^{73}$ La coronación y la realeza han sido señalados como elementos de gran importancia en la constitución de identidades africanas y sus descendientes en Brasil como hemos visto más arriba. Las raíces africanas de la coronación de reyes negros recuperaban de algún modo marcas de una identidad tribal y en el contexto de la diáspora reforzaba antiguas pertenencias, reconstruía memorias y creaba nuevas diferenciaciones. ${ }^{74}$

\section{Conclusiones}

En un artículo publicado en el año 2000 William Taylor presentaba una imagen acerca de los estudios sobre la Iglesia católica y la religión en la época colonial caracterizada por la bifurcación. Un camino llevaba a las investigaciones referidas a las instituciones y las autoridades eclesiásticas y el otro - atento a las expresiones de la religiosidad popular - sugería la existencia de un tipo de religión practicada casi completamente por fuera, y en contra, de la Iglesia institucional. La visión resultante de ambas aproximaciones no podía ser sino la de una serie de diferentes dualidades: la jerarquía eclesiástica y la religión popular, la Iglesia poderosa y la Iglesia débil, la alta y la baja religión, la Iglesia y el Estado o lo sagrado y lo secular. ${ }^{75}$

Estas imágenes bifurcadas se derivan, según los casos, de compromisos ideológicos o de posicionamientos historiográficos que recortaron los escenarios - y las escenas - en los lugares menos adecuados, allí justo donde se invisibiliza el diálogo. A propósito de estos recortes Taylor se preguntaba si, por ejemplo, era posible que los curas párrocos debatieran sus responsabilidades pastorales entre sí y prescindiendo de los feligreses, si era viable que estos últimos - en muchos casos auxiliares de los párrocos o mayordomos de las cofradías - se encontraran aislados y sin contactos con las estructuras de poder eclesiásticas, incluso con la jerarquía de esta Iglesia profesional o,

\footnotetext{
73 Archivo General de la Nación (Buenos Aires), Periodo colonial. Gobierno IX 36-4-3 doc. 10, cit. por CIRIO, Norberto Pablo. ¿Rezan o bailan?, op. cit., 2000, p. 92.

${ }^{74}$ OLIVEIRA, Anderson José Machado de. Devoção, op. cit., 2006; SOUZA, Marina de Mello e. Reis negros no Brasil escravista: história da festa de coroação de rei Congo. Belo Horizonte: UFMG, 2002.

75 TAYLOR, William. La Iglesia entre la jerarquía y la religión popular: Mensajes de la zona de contacto. In: CONNAUGHTON, B. (ed.). Historia de América Latina, v. 1. México: Unam, 2000, p. 177-226.
} 
REVISTA DE HISTÓRIA

SÃO PAULO, N 169 , p. 145-180,

JULHO / DEZEMBRO 2013
María Elena Barral

La Iglesia católica en Iberoamérica: las instituciones locales en una época de cambios (siglo XVIII)

en otras palabras, sobre las condiciones de posibilidad de la gestión de una religión local prescindiendo de la intervención de los eclesiásticos.

Como modo de superar estas dicotomías Taylor proponía en aquel artículo la noción de "zona de contacto": un campo de poder y de mediación donde podían interactuar esa Iglesia institucional y la religión popular. Esta interacción podía concretarse a partir de diferentes tipos de intersecciones localizadas en figuras e instituciones religiosas locales, en la fábrica material de las iglesias parroquiales o en los movimientos de grupos de pobladores motivados por ideas y devociones religiosas.

De modo que esta noción de "zona de contacto" se presenta como una plataforma donde es posible entablar distintos diálogos y uno de ellos orienta una más intensa integración de la Iglesia y de la religión al estudio de la historia colonial. Este tipo de desplazamientos construyen, por su parte, una historia más relacionada, superpuesta y contextualizada y nos devuelve imágenes menos dicotómicas: la de unos pastores trabajando en sus parroquias o doctrinas junto a sus feligreses o la de éstos recreando una religión local junto a sus párrocos, más que en su contra. En estas imágenes, los protagonistas de estas historias dejan de verse en una suerte de monólogos paralelos para resituarse en nuevos diálogos, en frecuentes ocasiones, atravesados de fuertes tensiones.

La historia de las instituciones eclesiásticas y religiosas locales durante el siglo XVIII, que hemos analizado en este artículo, se ha nutrido de una producción historiográfica dispuesta a entablar estos diálogos. ${ }^{76}$ Estas investigaciones ligan territorios historiográficos en ocasiones distanciados entre sí y sus resultados multiplican preguntas y horizontes de trabajo. El recorrido aquí realizado a propósito de las parroquias y las cofradías revela algunos de sus interesantes resultados y nos devuelven nuevos y enriquecidos problemas historiográficos como el papel de las estructuras y autoridades del poder eclesiástico en la creación de un orden institucional en las regiones que se incorporaban al control colonial (como hemos señalado para los casos de Buenos Aires y Minas Gerais); las cofradías y su intervención en la organización de la supervivencia y la reconstitución de las identidades étnicas (como señalamos para las cofradías de indios en el caso de Hispanoamérica y para las cofradías de negros en América portuguesa y española); estas hermandades y su función de sostenimiento de la vida religiosa en ausencia

\footnotetext{
${ }^{76}$ Una puesta de los estudios sobre la historia de la Iglesia y de la religión desde esta perspectiva puede verse en: AYROLO, Valentina, BARRAL, María Elena y DI STEFANO, Roberto. Catolicismo y secularización. Argentina, primera mitad del siglo XIX. Buenos Aires: Biblos, 2012.
} 
REVISTA DE HISTÓRIA

SÃO PAULO, N ${ }^{\circ} 169$, p. 145-180,

JULHO / DEZEMBRO 2013
María Elena Barral

La Iglesia católica en Iberoamérica: las instituciones locales en una época de cambios (siglo XVIII)

del clero regular (como sucedió en Minas Gerais), los cargos asociados a la gestión religiosa como modo de evadir las obligaciones y presiones del orden colonial, entre muchos otros.

Cada una de estas aproximaciones ofrece oportunidades para analizar el modo preciso en que se enlazaba lo secular y lo sagrado, la Iglesia profesional y las religiones locales, los laicos y los eclesiásticos a lo largo de un proceso de negociación pleno de tensiones. Estas aparentes dicotomías entraban en diálogo a partir de un tipo de relación pactada y construida sobre la base de la imposición de límites y también de la tolerancia entre sacerdotes y feligreses.

Los reformistas ibéricos probablemente minimizaron los desequilibrios que sus intervenciones podían desencadenar. Una parte del clero padeció distintos aspectos de las reformas y cuando la Corona buscó su incondicionalidad no siempre la encontró. El caso mexicano, el mejor estudiado sobre la politización revolucionaria del clero, ${ }^{77}$ lo muestra liderando la protesta colectiva, adhiriendo al movimiento insurgente o con una mayoritaria - y desencantada - neutralidad. Esta neutralidad se había fraguado en las últimas décadas coloniales en el contexto de la implantación de las medidas borbónicas. Los feligreses indios tuvieron sus propias motivaciones al formar parte de la Insurgencia. Estas razones también fueron seculares y sagradas. La intransigencia borbónica había arrasado con muchos de los acuerdos en ambos terrenos y algunas de sus consecuencias serían la erosión de la legitimidad y de la obediencia hacia las autoridades coloniales.

\section{Referencias Bibliograficas}

AYROLO, Valentina, BARRAL, María Elena y DI STEFANO, Roberto. Catolicismo y secularización. Argentina, primera mitad del siglo XIX. Buenos Aires: Biblos, 2012.

BARRAL, María Elena. De sotanas por la pampa. Religión y sociedad en Buenos Aires rural tardocolonial. Buenos Aires: Prometeo Libros, 2007.

Las parroquias del suroriente entrerriano a fines del siglo XVIII: los conflictos en Gualeguay. In: POLIMENE, María Paula (coord.). Autoridades y prácticas judiciales en el Antiguo Régimen. Problemas jurisdiccionales en el Río de la Plata, Córdoba, Tucumán, Cuyo y Chile. Rosario: Prohistoria, 2011, p. 95-115.

Alboroto, ritual y poder en los procesos de institucionalización de un área periférica del litoral rioplatense (Gualeguay, fines del siglo XVIII). Fronteras de la historia, v. 17-2, 2012, p. 129-158.

${ }_{77}$ TAYLOR, William. Ministros de lo sagrado, op. cit., 1999. 
REVISTA DE HISTÓRIA

SÃO PAULO, N 169 , p. 145-180,

JULHO / DEZEMBRO 2013
María Elena Barral

La Iglesia católica en Iberoamérica: las instituciones locales en una época de cambios (siglo XVIII)

BARRAL, María Elena y FRADKIN, Raúl. Los pueblos y la construcción de las estructuras de poder institucional en la campaña bonaerense (1785-1836). Boletín del Instituto de Historia Argentina y Americana "Dr. Emilio Ravignani", no 27, 2005, p. 7-48.

BECHTLOFF, Dagmar. La formación de una sociedad intercultural: Las cofradías en el Michoacán colonial. Historia Mexicana, v. 43, n² 2, 1993, p. 251-263.

BOSCHI, Caio César. Os leigos e o poder: irmandades leigas e política colonizadora em Minas Gerais. São Paulo: Ática, 1986.

BRADING, David. Una Iglesia asediada: el obispado de Michoacán, 1749-1810. México: FCE, 1994.

CELESTINO, Olinda y MEYERS, Albert. Las cofradías en el Perú: región central. Frankfurt-Main: Verlag Klaus Dieter Vervuert, 1981.

CHRISTIAN, Williams. Religiosidad local en la España de Felipe II. Madrid: Nerea, 1991.

CIRIO, Norberto Pablo. ¿Rezan o bailan? Disputas en torno a la devoción a san Baltazar por los negros en el Buenos Aires colonial. In: IV REUNIÓN CIENTÍFICA: MUJERES, NEGROS Y NIÑOS EN LA MÚSICA Y SOCIEDAD COLONIAL IBEROAMERICANA Actas. Edit. par V. Rondón. Santa Cruz de la Sierra: Asociación Pro Arte y Cultura, p. 88-100.

CURIEL, José Refugio de La Torre. Vicarios en entredicho. Zamora/Guadalajara: El Colegio de Michoacán, Universidad de Guadalajara, 2001.

DE LA HERA, Alberto. El regalismo indiano. IusCanonicum, nº 64. Pamplona: EUNSA, 1992, p. 411-437.

DJENDEREDJIAN, Julio. Economía y sociedad en la Arcadia criolla. Formación y desarrollo de una sociedad de frontera en Entre Ríos, 1750-1820. Tesis de doctorado, Universidad de Buenos Aires (Argentina), 2003.

ELLIOT, John H. Rey y patria en el mundo hispánico. In: MÍNGUEZ, Víctor y CHUST, Manuel. El imperio sublevado. Monarquía y naciones en España e Hispanoamérica. Madrid: CSIC, 2004, p. 17-36.

ESTRADA, Dorothy Tanck de. Pueblos de indios y educación en el México colonial, 17501821. México: El Colegio de México, 2000.

FEITLER, Bruno y SOUZA, Evergton Sales (orgs.). A Igreja no Brasil: Normas e práticas durante a vigência das Constituições Primeiras do Arcebispado da Bahia. São Paulo: Editora Unifesp, 2011.

FONSECA, Claudia Damasceno. Des terres aux villes de l'or. Pouvoirs et territoires urbains au Minas Gerais (Brésil, XVIII siècle). Paris: Publications du Centre Culturel Calouste Gulbenkian, 2003.

Freguesias e capelas. In: FEITLER, Bruno y SOUZA, Evergton Sales (org.). A Igreja no Brasil: Normas e práticas durante a vigência das Constituições Primeiras do Arcebispado da Bahia. São Paulo: Editora Unifesp, 2011, p. 425-452.

FRADKIN, Raúl y GARAVAGLIA, Juan Carlos. La Argentina colonial. El Río de la Plata entre los siglos XIV y XIX. Buenos Aires: Siglo XXI, 2009.

GARAVAGLIA, Juan Carlos y MARCHENA, Juan. América Latina. De los orígenes a la Independencia, vol. 2. Barcelona: Crítica, 2005. 
REVISTA DE HISTÓRIA

SÃO PAULO, N ${ }^{\circ} 169$, p. 145-180,

JULHO / DEZEMBRO 2013
María Elena Barral

La Iglesia católica en Iberoamérica: las instituciones locales en una época de cambios (siglo XVIII)

HÜNEFELDT, Christine. Comunidad, curas y caciques hacia fines del período colonial: ovejas y pastores indomados en el Perú. HISLA, n² 2, 1983, p. 3-31.

IOGNA-PRATT, Dominique y ZADORA-RIO, Élisabeth. Formation et transformations des territoires paroissiaux. Médiévales, n² 49, 2005, p. 5-10.

LAUWERS, Michel. Paroisse, paroissiens et territoire. Remarques sur parochia dans les textes latins du Moyen Âge. Médiévales, n49, 2005, p. 11-32.

LAVALLE, Bernard. Las doctrinas de indígenas como núcleos de explotación colonial (siglos XVI-XVIll). Allpanchis, v. 16, n 19. Cusco, 1982, p. 151-171.

LOCKHART, James. Organización y cambio social en la América española colonial. In: BETHELL, Leslie (ed.). Historia de América Latina, tomo 4. Barcelona: Crítica, 1990, p. 63-108.

MANCUSO, Laura. Cofradías mineras: religiosidad popular en México y Brasil, siglo XVIII. México: El Colegio de México, 2007.

MARTINS, William de Souza. Membros do corpo místico. Ordens terceiras no Rio de Janeiro (c. 1700-1822). São Paulo: Edusp, 2009.

MOSCOSO, Sabrina Guerra. La disputa por el control de las doctrinas en la Real Audiencia de Quito: Un estudio microhistórico sobre la tensión entre y dentro del Estado, la Iglesia $y$ las redes de poder local. Guano, siglo XVIII. Tesis doctoral, Universitat Jaume I, Castellón, 2008.

MOVELLÁN, Tomás Mantecón. Contrarreforma y religiosidad popular en Cantabria. Las cofradías religiosas. Santander: Universidad de Cantabria, 1990.

MOVELLÁN, Tomás Mantecón. El peso de la infrajudicialidad en el control del crimen. Etudis: Revista de Historia Moderna, n 28, Universidad de Valencia, 2002, p. 43-75.

MAZIN, Oscar, MENEGUS, Margarita y MORALES, Francisco. La secularización de las doctrinas de indios en la Nueva España. La pugna entre las dos iglesias. México: Bonilla Artiaga Editores/Unam, 2010.

MEDRANO, Carlos Rubén Ruiz. El tumulto de 1767 en Guanajuato. Estudios de Historia Novohispana, v. 19. México: Unam, 1999, p. 13-46.

MULVEY, Patricia A. Slave confraternities in Brazil: Their role in colonial society. The Americas, v. 39, nº 1, 1982, p. 39-68.

NAJAS, Rosemarie Terán. La Iglesia en los Andes en el siglo XVIII. Historia de la América andina: el sistema colonial tardío. Quito: UASB, 2001, p. 183-214.

OLIVEIRA, Anderson José Machado de. Devoção e identidades: significados do culto de Santo Elesbão e Santa Efigênia no Rio de Janeiro e nas Minas Gerais no Setecentos. Topoi, $\mathrm{n}^{\circ}$ 12, 2006, p. 60-115.

PUENTE, Leticia Pérez. Dos proyectos postergados. El tercer Concilio Provincial mexicano y la secularización parroquial. Estudios de Historia Novohispana, $\mathrm{n}^{\circ} 35$, 2006, p 17-45.

RAMOS, Donald. Community, control, and acculturation: A case study of slavery in eighteenth century Brazil. The Americas, v. 42, $\mathrm{n}^{\circ} 4,1986$, p. 419-451.

ROBINS, Nicholas. Comunidad, clero y conflicto. Las relaciones entre la curia y los indios en el Alto Perú, 1750-1780. La Paz: Plural, 2009. 
REVISTA DE HISTÓRIA

SÃO PAULO, N 169 , p. 145-180,

JULHO / DEZEMBRO 2013
María Elena Barral

La Iglesia católica en Iberoamérica: las instituciones locales en una época de cambios (siglo XVIII)

ROCHER SALAS, Adriana. Frailes y clérigos en Yucatán, siglo XVII. Hispania Sacra, v. 55, $\mathrm{n}^{\circ}$ 112. Madrid: Consejo Superior de Investigaciones Científicas, 2003, p. 600-625.

RODRİGUEZ, Antonio Acosta. Los clérigos doctrineros y la economía colonial (Lima 1600-1630). Allpanchis, v. 16, n 19. Cusco, 1982, p. 117-150.

. La reforma eclesiástica y misional (siglo XVIII). In: TANDETER, Enrique e LEHUEDÉ, Jorge Hidalgo (dirs.). Historia general de América Latina, v. 4. París-Madrid: Unesco/Editorial Trotta, 2000, p. 349-374.

ROSAL, Miguel Ángel. Africanos y afrodescendientes en el Río de la Plata, siglos XVIII-XIX. Buenos Aires: Dunken, 2009.

RUSSELL-WOOD, A. J. R. Black and mulato brotherhoods in colonial Brazil: a study in collective behavior. HAHR, v. 54, no 4, 1974, p. 567-602.

RUZ, Mario Humberto. Una muerte auxiliada. Cofradías y hermandades en el mundo maya colonial. Relaciones, v. 24, nº 94. Zamora/México: Colegio de Michoacan, 2003, p. 19-58.

SALVADOR, Rodolfo Aguirre. La demanda de clérigos "lenguas" del arzobispado de México, 1700-1749. Estudios de Historia Novohispana, nº 35, 2006, p. 47-70.

. La secularización de doctrinas en el arzobispado de México: realidades indianas y razones políticas, 1700-1749. Hispania Sacra, v. 60, n² 122, 2008, p. 487-505.

. José Lanciego, arzobispo de México, y el clero regular durante la transición eclesiástica del reinado de Felipe V, 1712-1728. Fronteras de la Historia, v. 17-2/2012, p. 75-100.

SERULNIKOV, Sergio. Conflictos sociales e insurrección en el mundo colonial andino. El norte de Potosí en el siglo XVIII. México: FCE, 2006.

SILVA, Luiz Geraldo. "Sementes da sediçao": etnia, revolta escrava e controle social na América portuguesa (1808-1817). Afro-Ásia, n² 25-26, 2001, p. 9-60.

Religião e identidade étnica. Africanos, crioulos e irmandades na América portuguesa. Cahiers des Amériques Latines, v. 44, 2003, p. 77-96.

SILVEIRA, Marco Antonio. O universo do indistinto. Estado e sociedade nas Minas setecentista (1735-1808). São Paulo: Hucitec, 1997.

SOUZA, Marina de Mello e. Reis negros no Brasil escravista: história da festa de coroação de rei Congo. Belo Horizonte: UFMG, 2002.

SOUZA, Evergton Sales. Igreja e Estado no período pombalino. Lusitania Sacra, $\mathrm{n}^{\circ}$ 23, 2011, p. 207-230.

STERN Stern. La era de la insurrección andina, 1742-1782: una reinterpretación. In: STERN, S. Resistencia, rebelión y conciencia campesina en los Andes, siglos XVIII al $X X$. Lima: IEP, 1990, p. 50-96.

TAYLOR, William. Bandolerismo e insurrección. Agitación social en el centro de Jalisco, 1790-1816. In: KATZ, F. Revuelta, rebelión y revolución. La lucha rural en México del siglo XVI al siglo XX. México: Era, 1990, p. 187-223.

. El camino de los curas y de los Borbones hacia la modernidad. In: MATUTE, Álvaro, TREJO, Evelia y CONNAGHTON, Brian (coords.). Estado, Iglesia y sociedad en México, siglo XIX. México: Unam-Miguel Angel Porrúa ed., 1995, p. 81-113. 
Embriaguez, homicidio y rebelión en las poblaciones coloniales mexicanas. México: FCE, 1987.

. Ministros de lo sagrado: sacerdotes y feligreses en el México del siglo XVIII. Zamora, Michoacán: Colegio de Michoacán-Secretaría de Gobernación-El Colegio de México, 1999.

. La Iglesia entre la jerarquía y la religión popular: Mensajes de la zona de contacto. In: CONNAUGHTON, B. (ed,). Historia de América Latina, v. 1. México: Unam, 2000, p. 177-226.

VALLEJOS, Julio Pinto. Slave control and slave resistance in colonial Minas Gerais, 1700-1750. Journal of Latin American Studies, v. 17, part 1, 1985, p. 1-34.

VEGA, Walter. Cofradías en el Perú colonial: una aproximación bibliográfica. Diálogos, $\mathrm{n}^{\circ} 1,1999$, p. 137-152.

WOBESER, Gisela von. Dominación colonial; la consolidación de vales reales en Nueva España, 1804-1812. México: Unam, 2003

WOBESER, Gisela von. El crédito eclesiástico en la Nueva España siglo XVIII. México: Unam, 1994.

ZADORA-RIO, Élisabeth. Territoires paroissiaux et construction de l'espace vernaculaire. Médiévales, 49, 2005, p. 105-120.

Recebido: 15/03/2013 - Aprovado: 28/06/2013 